\title{
Design, synthesis, and antiproliferative effect of 2,9-bis[4- (pyridinylalkylaminomethyl)phenyl]-1,10-phenanthroline derivatives on human leukemic cells by targeting G-quadruplex
}

\author{
Jean Guillon ${ }^{1}$ (1) | Caroline Denevault-Sabourin ${ }^{2}$ | Edith Chevret $^{3}$ | \\ Marie Brachet-Botineau $^{2,4}$ | Vittoria Milano ${ }^{1}$ | Aurore Guédin-Beaurepaire ${ }^{1}$ \\ Stéphane Moreau ${ }^{1}$ | Luisa Ronga ${ }^{5}$ | Solène Savrimoutou ${ }^{1}$ | Sandra Rubio ${ }^{1}$ | \\ Jacky Ferrer $^{3}$ | Jeremy Lamarche ${ }^{5}$ | Jean-Louis Mergny ${ }^{1,6}$ | \\ Marie-Claude Viaud-Massuard ${ }^{2}$ | Matthieu Ranz ${ }^{7}$ | Eric Largy ${ }^{7}$ | \\ Valérie Gabelica $^{7}$ | Frédéric Rosu ${ }^{8}$ | Fabrice Gouilleux ${ }^{4}$ | Vanessa Desplat ${ }^{9}$
}

\footnotetext{
${ }^{1}$ ARNA Laboratory, Université de Bordeaux, INSERM U1212, CNRS UMR 5320, UFR des Sciences Pharmaceutiques, Bordeaux, France

${ }^{2}$ Groupe Innovation et Ciblage Cellulaire, UFR des Sciences Pharmaceutiques, Université Tours, EA GICC-ERL 7001 CNRS, Tours, France

${ }^{3}$ Cutaneous Lymphoma Oncogenesis Team, Bordeaux Research in Translational Oncology (BaRITOn), Université Bordeaux, INSERM U1053, Bordeaux, France ${ }^{4}$ Service d'Hématologie Biologique, CHRU de Tours, Tours, France

${ }^{5}$ Institut des Sciences Analytiques et de Physico-Chimie pour l'Environnement et les Matériaux, Université de Pau et des Pays de l'Adour, E2S UPPA, CNRS UMR 5254, IPREM, Pau, France

${ }^{6}$ Institute of Biophysics, Czech Academy of Sciences, v.v.i., Brno, Czech Republic

${ }^{7}$ ARNA Laboratory, Université de Bordeaux, INSERM U1212, CNRS UMR 5320, Institut Européen de Chimie et Biologie, Pessac, France

${ }^{8}$ IECB (Institut Européen de Chimie et Biologie), Université Bordeaux, CNRS, INSERM, UMS 3033 US001, Pessac, France

${ }^{9}$ Cellules souches hématopoḯtiques normales et leucémiques, UFR des Sciences Pharmaceutiques, Université Bordeaux, INSERM, U1035, Bordeaux, France
}

\section{Correspondence}

Jean Guillon, Université Bordeaux, CNRS, INSERM, ARNA, UMR 5320, U1212, F-33000 Bordeaux, France.

Email: jean.guillon@u-bordeaux.fr

\begin{abstract}
Current multiagent chemotherapy regimens have improved the cure rate in acute leukemia patients, but they are highly toxic and poorly efficient in relapsed patients. To improve the treatment approaches, new specific molecules are needed. The G-quadruplexes (G4s), which are noncanonical nucleic acid structures found in specific guanine-rich DNA or RNA, are involved in many cellular events, including control of gene expression. G4s are considered as targets for the development of anticancer agents. Heterocyclic molecules are well known to target and stabilize G4 structures. Thus, a new series of 2,9-bis [(substituted-aminomethyl)phenyl]-1,10-phenanthroline derivatives (1a-i) was designed, synthesized, and evaluated against five human myeloid leukemia cell lines (K562, KU812, MV4-11, HL60, and U937). Their ability to stabilize various oncogene promoter G4 structures (c-MYC, BCL-2, and K-RAS) as well as the telomeric G4 was also determined through the fluorescence resonance energy transfer melting assay and native mass spectrometry. In addition, the more
\end{abstract}


bioactive ligands $1 \mathrm{~g}-\mathbf{i}$ were tested for telomerase activity in HuT78 and MV411 protein extracts.

\section{KEYWORDS}

1, 10-phenanthroline, antiproliferative activity, FRET melting, G4 ligands, G-quadruplex, leukemia

\section{1 | INTRODUCTION}

Acute leukemia is a malignant disorder characterized by a blockade of hematopoietic stem cell differentiation. This leads to a high level of immature malignant cells, named blasts. Blast cells accumulate in the bone marrow (BM) and peripheral blood. Acute leukemia prognosis is variable, based on clinical features and leukemia-specific genetic features including cytogenetic and molecular classifications. The main treatment involves the long-term use of chemotherapy, but there is a high incidence of relapses in adults, unlike children for whom the prognosis is better. In the last few years, a better understanding of acute leukemia pathophysiology has highlighted several potential therapeutic targets allowing the development of new, more selective therapeutic agents, to improve the overall survival in patients. ${ }^{[1-3]}$

Telomerase is a ribonucleoprotein reverse transcriptase enzyme that can add telomere repeats to telomere DNA to maintain chromosome stability and integrity. Furthermore, telomerase acts as a key regulator of long-term proliferation. As $85-90 \%$ of cancer cells display telomerase activity, which enables them to proliferate indefinitely and be immortal, telomerase can be considered as an interesting target for cancer chemotherapies. Moreover, most leukemic cells are generally telomerase-positive and often have shortened telomeres. The rationale for targeting telomeric DNA with drugs is that if the telomere overhang DNA forms higher order structures, such as G-quadruplexes (G4s), the telomere capping machinery, including the telomerase, is perturbed. ${ }^{[4]}$

The G4s are single-stranded guanine-rich nucleic acid sequences that may fold into noncanonical four-stranded secondary structures. These structures are formed through л-л stacking of Gquartets that involve four guanines organized in a plane via eight Hoogsteen-type $\mathrm{H}$-bonding. G4 structures are stabilized in the presence of monovalent cations, such as $\mathrm{K}^{+}$or $\mathrm{Na}^{+}$. In addition, G4forming motifs have been identified in oncogene promoter regions, bringing to light the therapeutic potential for targeted gene regulation at the transcriptional level. The most studied oncogene promoter G4s include c-MYC, Bcl-2, h-RAS, K-RAS, and c-KIT. Thus, both inhibition of telomerase activity through G4 structure stabilization and induction of the DNA damage response through telomere uncapping can prompt a proliferation arrest, resulting in anticancer activity. Hence, small molecules that can target and stabilize G4 structures in the human genome could act as potential and interesting anticancer agents. ${ }^{[5-7]}$
The large planar aromatic surface of a terminal G-quartet provided a rationale for the design and development of planar G4 ligands such as polyaromatic fused molecules, which include acridines, phenanthroline, quinolone, and quinone. ${ }^{[8-13]}$ On the basis of these chemical pharmacophores, a number of G4-binding molecules have been designed and developed as potential anticancer agents during the last two decades, such as SYUIQ-5, SYUIQ-FM05, Tz1, quarfloxin, or GTC365 (Figure 1). ${ }^{[9-14]}$ Many of these heterocyclic ligands are selective for $\mathrm{G} 4$ structures over duplex DNA, but the design of a ligand specific for a given G4 structure is still challenging. Among them, APTO-253, a small-molecule 2-indolylimidazole[4,5-d]phenanthroline derivative (Figure 1), is currently undergoing clinical development for the treatment of acute myeloid leukemia ( $A M L)$. APTO-253 was advanced into a phase I clinical trial in patients with relapsed/refractory hematologic malignancies with emphasis on AML. Moreover, APTO-253 seems to inhibit the expression of the cMYC oncogene, leading to cell cycle arrest and programmed cell death (apoptosis) in human-derived solid tumor and hematologic cancer cells. ${ }^{[15-17]}$

In the course of our work devoted to the discovery of new heterocycles for use in anticancer chemotherapies, ${ }^{[18-23]}$ we previously designed and prepared a series of new substituted 2,9-bis [(substituted-aminomethyl)phenyl]-1,10-phenanthroline derivatives A (Figure 1), which were designed to bind to DNA Gquadruplexes $^{[24,25]}$ and endowed with interesting activity toward human leukemia cells. ${ }^{[24]}$ In this context and by considering the biological activities of these previous 2,9-bis[(substitutedaminomethyl)phenyl]-1,10-phenanthrolines against human leukemic cells, we have undertaken the synthesis of a new series of 2,9-bis[(substituted-aminomethyl)phenyl]-1,10-phenanthroline derivatives $1 \mathbf{a}-\mathbf{i}$. The extended planar aromatic structure of the 1,10-phenanthroline scaffold provides a basis for efficient $\pi-\pi$ stacking interactions with G-quartets. ${ }^{[26]}$ In this study, we designed and synthesized new phenanthroline derivatives $1 \mathrm{a}-\mathbf{i}$ substituted with various pyridinylalkylamine chains on the benzyl moieties (Figure 1). We hypothesized that such substitutions at positions 2 and 9 could lead to more potent G4 ligands in terms of selectivity by providing extra aromatic groups. We reasoned that the extended aromatic structures of these pyridinylalkylaminobenzyl groups could provide a basis for further $\pi-\pi$ stacking interactions with the G-quartets and that the length of the amine side chains should influence the stabilizing potential of the ligands. We evaluated ligand-induced stabilization, specificity, and selectivity of the newly synthesized phenanthroline 
<smiles>CN(C)CCCNc1c2ccccc2nc2c1[nH]c1ccccc12</smiles>

SYUIQ-5<smiles></smiles>

SYUIQ-FM05<smiles>CN1CCC[C@H]1CCNC(=O)c1cn2c3c(c(N4CC[C@@H](c5cnccn5)C4)c(F)cc3c1=O)Oc1cc3ccccc3cc1-2</smiles>

Quarfloxin (CX-3543)<smiles>N=C(N)NCCS(=O)(=O)Nc1ccc(Nc2c3ccccc3nc3cc([N+](=O)[O-])ccc23)cc1</smiles><smiles>[Y7][Y]</smiles><smiles>Cc1[nH]c2ccc(F)cc2c1-c1nc2c3cccnc3c3ncccc3c2[nH]1</smiles>

APTO-253<smiles>[R]N([R])CCCNCCCNCCNCCCN([R])[R]</smiles><smiles>[R]N([R])CCCCCCC</smiles>

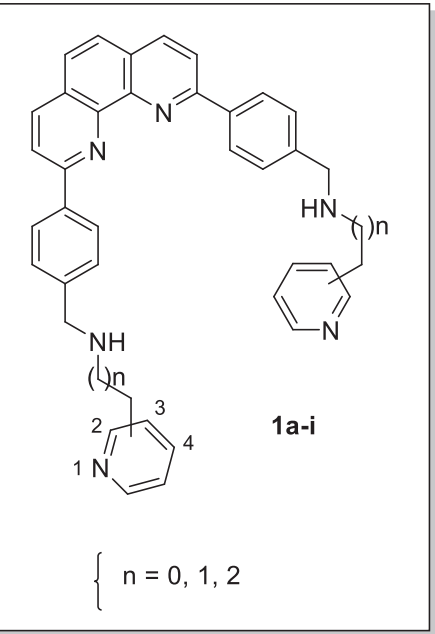

FIGURE 1 The structures of SYUIQ-5, SYUIQ-FM05, quarfloxin, GTC365, Tz1, APTO-253, phenanthrolines, A and the newly designed 2,9bis[4-(pyridinylalkylaminomethyl)phenyl]-1,10-phenanthroline derivatives 1a-i

derivatives for various oncogene promoter G4 topologies including C-MYC, BCL-2, and K-RAS through fluorescence resonance energy transfer (FRET) melting experiments. The antiproliferative activity of the obtained derivatives $1 \mathbf{a}-\mathbf{i}$ was then evaluated in vitro against various hematologic malignant cell lines ( $\mathrm{K} 562$, KU812, MV4-11, HL60, and U937). In addition, their cytotoxicity against the HS27a stromal cell line was also evaluated to determine an index of selectivity toward cancer cells. Next, telomerase inhibition ability has been assessed for the more bioactive ligands $1 \mathrm{~g}-\mathbf{i}$ using two cell lines (HuT78 and MV-4-11).

\section{RESULTS AND DISCUSSION}

\section{1 | Chemistry}

The reported 2,9-bis[4-(pyridinylalkylaminomethyl)phenyl]-1,10phenanthroline derivatives $1 \mathbf{a}-\mathbf{i}$ were synthesized starting from the commercially available 2,9-dichloro-1,10-phenanthroline 2 (Scheme 1). The bis-[2,9-(formylphenyl)]-1,10-phenanthroline 3 was prepared by a direct, double Suzuki-Miyaura cross-coupling reaction of 2,9-dichloro1,10-phenanthroline 2 with the 4-formylphenylboronic acid in the 


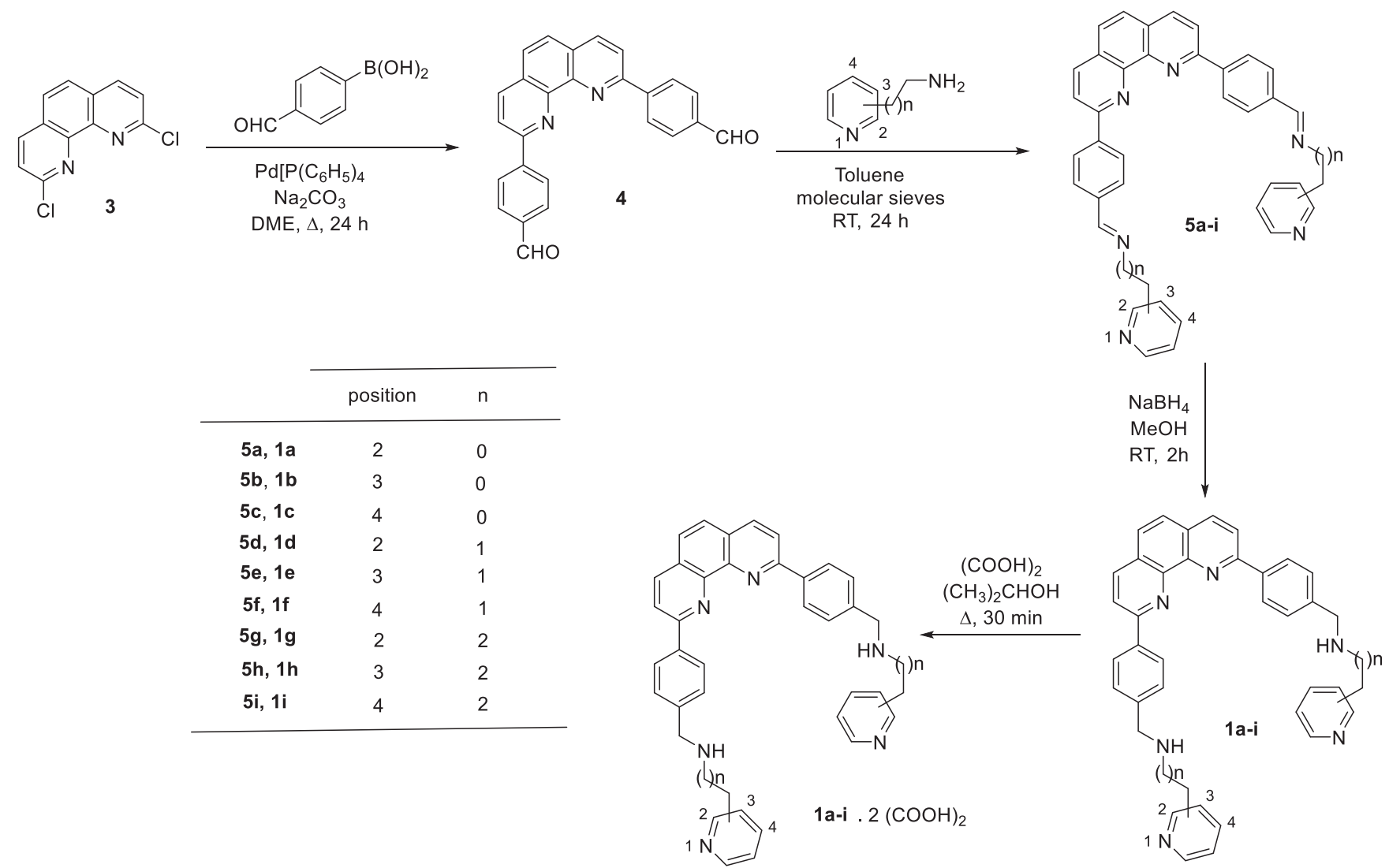

SCHEME 1 General procedure for the preparation of target compounds $1 \mathrm{a}-\mathbf{i}$

presence of $\mathrm{Pd}\left(\mathrm{PPh}_{3}\right)_{4}$ as a catalyst and sodium carbonate as the base. ${ }^{[24,25]}$ Reaction of primary substituted pyridinylalkylamines with 3 gave the di-imines $4 a-i$, which were reduced into the 2,9-bis[4(pyridinylalkylaminomethyl)phenyl]-1,10-phenanthrolines 1a-i using sodium borohydride in methanol, as previously described. ${ }^{[2,25]}$ These phenanthroline compounds, $\mathbf{1} \mathbf{a}-\mathbf{i}$, were then converted into their ammonium oxalate salts by treatment with oxalic acid in refluxing isopropanol. Table 1 summarizes the physical properties of the $1 \mathbf{a}-\mathbf{i}$ oxalates.

\section{2 | Biological evaluation}

The cytotoxic activity of these newly synthesized 2,9-bis[4(pyridinylalkylaminomethyl)phenyl]-1,10-phenanthroline derivatives 1a-i was then evaluated against the K562, KU812, MV4-11, HL60, and $\mathrm{U} 937$ hematologic malignant cell lines with proliferation assays, using derivative APTO-253 as the reference standard drug.

As noticed in Table 2, the $\mathrm{IC}_{50}$ values of 2,9-bis-substituted1,10-phenanthroline derivatives $1 \mathrm{a}-\mathbf{i}$ were found ranging from 1.3 to $19.0 \mu \mathrm{M}$. Against the human K562 chronic myeloid leukemia cell line, the 2,9-bis[4-(pyridinylalkylaminomethyl)phenyl]1,10-phenanthroline derivatives $1 \mathbf{a}-\mathbf{i}$ showed some significant antiproliferative activities, with $\mathrm{IC}_{50}$ determined between 3.9 and $5.3 \mu \mathrm{M}$, whereas APTO-253 showed a modest antiproliferative activity of $35.6 \mu \mathrm{M}$ against this same leukemia cell line. Among the nine 1,10-phenanthrolines 1a-i tested for antiproliferative activities against the basophilic leukemia KU812 cell line, the 1,10-phenanthroline $1 \mathbf{i}$ was found to be the most biologically active compound with an $\mathrm{IC}_{50}$ of $1.6 \mu \mathrm{M}$. In

TABLE 1 Physical properties of amines 1a-i

\begin{tabular}{lllll} 
Compound & & Salt $^{\mathrm{a}}$ & $\mathrm{MP}\left({ }^{\circ} \mathrm{C}\right)^{\mathrm{b}}$ & $\%$ Yield $^{\mathrm{c}}$ \\
\hline 1a & Pale yellow crystals & $2(\mathrm{COOH})_{2}$ & $187-189$ & 75 \\
\hline 1b & Yellow crystals & $2(\mathrm{COOH})_{2}$ & $222-224$ & 62 \\
\hline 1c & Pale yellow crystals & $2(\mathrm{COOH})_{2}$ & $180-182$ & 89 \\
\hline 1d & Yellow crystals & $2(\mathrm{COOH})_{2}$ & $182-184$ & 72 \\
\hline 1e & Yellow crystals & $2(\mathrm{COOH})_{2}$ & $181-183$ & 95 \\
\hline 1f & Yellow crystals & $2(\mathrm{COOH})_{2}$ & $187-189$ & 81 \\
\hline 1g & Yellow crystals & $2(\mathrm{COOH})_{2}$ & $141-143$ & 75 \\
\hline 1h & Yellow crystals & $2(\mathrm{COOH})_{2}$ & $134-136$ & 78 \\
\hline 1i & Yellow crystals & $2(\mathrm{COOH})_{2}$ & $139-141$ & 80 \\
\hline
\end{tabular}

aThe stoichiometry and composition of the salts were determined by elemental analyses, and obtained values were within $\pm 0.4 \%$ of the theoretical values.

${ }^{b}$ Crystallization solvent: 2- $\mathrm{PrOH}-\mathrm{H}_{2} \mathrm{O}$.

'The yields only included the conversions into the ammonium oxalates. 
TABLE 2 In vitro activity of compounds $1 \mathbf{a}-\mathbf{i}$ against five human myeloid leukemia cell lines, and cytotoxicity against the HS27a stromal cell line

\begin{tabular}{|c|c|c|c|c|c|c|}
\hline Compound & $\begin{array}{l}\text { K562 } \\
I C_{50}(\mu \mathrm{M})\end{array}$ & $\begin{array}{l}\text { KU812 } \\
\mathrm{IC}_{50}(\mu \mathrm{M})\end{array}$ & $\begin{array}{l}\text { MV4-11 } \\
I_{50}(\mu \mathrm{M})\end{array}$ & $\begin{array}{l}\text { HL60 } \\
I_{50}(\mu \mathrm{M})\end{array}$ & $\begin{array}{l}\text { U937 } \\
\mathrm{IC}_{50}(\mu \mathrm{M})\end{array}$ & $\begin{array}{l}\mathrm{HS} 27 \mathrm{a} \\
\mathrm{CC}_{50}(\mu \mathrm{M})\end{array}$ \\
\hline $1 a$ & $4.8 \pm 2.0$ & $2.1 \pm 0.4$ & $2.9 \pm 1.0$ & $3.5 \pm 0.9$ & $5.0 \pm 1.3$ & $11.5 \pm 4.0$ \\
\hline $1 b$ & $5.3 \pm 2.9$ & $4.6 \pm 1.0$ & $3.1 \pm 1.1$ & $8.0 \pm 1.2$ & $19.0 \pm 2.4$ & $4.1 \pm 0.5$ \\
\hline $1 c$ & $3.9 \pm 1.9$ & $4.1 \pm 0.9$ & $3.0 \pm 1.0$ & n.d. & $11.0 \pm 2.9$ & $23.6 \pm 1.1$ \\
\hline $1 d$ & $4.4 \pm 2.0$ & $2.9 \pm 0.8$ & $1.5 \pm 0.3$ & $3.0 \pm 1.0$ & $4.0 \pm 2.1$ & $3.4 \pm 1.3$ \\
\hline $1 e$ & $3.9 \pm 1.2$ & $2.4 \pm 0.9$ & $2.9 \pm 1.0$ & $3.5 \pm 1.1$ & $7.5 \pm 1.8$ & $3.6 \pm 1.7$ \\
\hline $1 f$ & $5.2 \pm 2.8$ & $2.6 \pm 0.4$ & $2.3 \pm 0.6$ & $3.0 \pm 0.7$ & $4.0 \pm 1.3$ & $3.7 \pm 1.5$ \\
\hline $1 g$ & $4.1 \pm 2.3$ & $2.5 \pm 0.7$ & $2.1 \pm 0.5$ & $3.0 \pm 1.0$ & $2.0 \pm 0.8$ & $4.1 \pm 2.4$ \\
\hline $1 \mathrm{~h}$ & $4.8 \pm 3.1$ & $2.4 \pm 0.7$ & $1.3 \pm 0.3$ & $8.0 \pm 0.9$ & $2.0 \pm 0.7$ & $4.2 \pm 2.5$ \\
\hline $1 i$ & $5.0 \pm 2.1$ & $1.6 \pm 0.5$ & $1.6 \pm 0.4$ & $3.0 \pm 0.8$ & $3.0 \pm 0.9$ & $5.1 \pm 1.0$ \\
\hline АРTO-253 & $35.6 \pm 1.8$ & $3.6 \pm 1.7$ & $0.3 \pm 0.1$ & n.d. & $<1$ & $4.0 \pm 1.2$ \\
\hline
\end{tabular}

Abbreviation: n.d., not done. addition, the 1,10-phenanthrolines $1 \mathrm{~g}-\mathbf{i}$, which were disubstituted with a $C_{3}$ pyridinyl chain, exhibited a better biological activity than their $\mathrm{C}_{1}$ or $\mathrm{C}_{2}$ homologs, compounds $1 \mathrm{a}-\mathrm{c}$ and $1 \mathrm{~d}-\mathrm{f}$, respectively, that is, $I_{50}$ of $1.6-2.5 \mu \mathrm{M}$ for $1 \mathrm{~g}-\mathrm{i}$ versus 2.4-2.9 $\mu \mathrm{M}$ for $1 \mathrm{~d}-\mathrm{f}$ and 2.1-4.6 $\mu \mathrm{M}$ for $1 \mathrm{a}-\mathrm{c}$. Moreover, against the KU812 cell line, derivative $1 \mathbf{i}$ bearing pyridin-4ylpropylaminomethyl side chains at position 4 of the benzyl rings displayed better activity than its analogs substituted with pyridin-3-ylpropylaminomethyl or pyridin-2-ylpropylaminometh$\mathrm{yl}$ side chains $\left(\mathrm{IC}_{50}=1.6 \mu \mathrm{M}\right.$ for $1 \mathrm{i}$ versus $\mathrm{IC}_{50}=2.4$ and $2.5 \mu \mathrm{M}$ for $1 \mathrm{~h}$ and $1 \mathrm{~g}$, respectively). Against the acute myeloid leukemia MV4-11 cell line, the biological results of compounds $1 a-i$ were

TABLE 3 Selectivity indexes of compounds $1 a-\mathbf{i}$

\begin{tabular}{|c|c|c|c|c|c|}
\hline \multirow[b]{2}{*}{ Compound } & \multicolumn{5}{|c|}{ Selectivity index ${ }^{a}$} \\
\hline & $\begin{array}{l}\text { HS27a/ } \\
\text { K562 }\end{array}$ & $\begin{array}{l}\text { HS27a/ } \\
\text { KU812 }\end{array}$ & $\begin{array}{l}\text { HS27a/ } \\
\text { MV4-11 }\end{array}$ & $\begin{array}{l}\text { HS27a/ } \\
\text { HL60 }\end{array}$ & $\begin{array}{l}\text { HS27a/ } \\
\text { U937 }\end{array}$ \\
\hline $1 a$ & 2.4 & 5.5 & 4.0 & 3.3 & 2.3 \\
\hline $1 b$ & 0.8 & 0.9 & 1.3 & 0.5 & 0.2 \\
\hline $1 c$ & 6.1 & 5.8 & 7.9 & n.d. & 2.1 \\
\hline $1 d$ & 0.8 & 1.2 & 2.3 & 1.1 & 0.9 \\
\hline $1 e$ & 0.9 & 1.5 & 1.2 & 1.0 & 0.5 \\
\hline $1 f$ & 0.7 & 1.4 & 1.6 & 1.2 & 0.9 \\
\hline $1 \mathrm{~g}$ & 1.0 & 1.6 & 1.9 & 1.4 & 2.1 \\
\hline $1 \mathrm{~h}$ & 0.9 & 1.7 & 3.2 & 0.5 & 2.1 \\
\hline $1 \mathrm{i}$ & 1.0 & 3.2 & 3.2 & 1.7 & 1.7 \\
\hline APTO-253 & 0.1 & 1.1 & 13.3 & n.d. & $>4.0$ \\
\hline
\end{tabular}

Abbreviations: n.d., not done; SI, selectively index.

${ }^{a} \mathrm{SI}$ was defined as the ratio between the $\mathrm{CC}_{50}$ value against the HS27a normal cells and the $\mathrm{IC}_{50}$ value against the leukemia K562, KU812, MV4-11, HL60, or U937 cells. found quite similar to those noticed against the KU812 cell line in terms of structure-activity relationships. These results exhibited a potent cytotoxicity for disubstituted pyridinylpropylaminomethyl phenanthrolines $1 \mathrm{~g}-\mathbf{i}$ ( $\left(\mathrm{C}_{50}\right.$ ranging from 1.3 to $\left.2.1 \mu \mathrm{M}\right)$, greater than that observed for disubstituted pyridinylethylaminomethyl phenanthrolines $1 \mathrm{e}-\mathrm{f}\left(\mathrm{IC}_{50}=2.3-2.9 \mu \mathrm{M}\right)$ and for disubstituted pyridinylmethylaminomethyl phenanthrolines $1 \mathrm{a}-\mathrm{c}$ $\left(I C_{50}=2.9-3.1 \mu \mathrm{M}\right)$. Surprisingly, disubstituted pyridinylethylaminomethyl phenanthroline $1 \mathrm{~d}$ showed an $\mathrm{IC}_{50}$ of $1.5 \mu \mathrm{M}$ in the same range as that observed for pyridinylpropylaminomethyl derivatives $\mathbf{1 g}$-i. Nevertheless, our tested phenanthrolines 1a-i were found less active than the reference APTO-253 phenanthroline, that is, $\mathrm{IC}_{50}=1.3-3.1 \mu \mathrm{M}$ for $1 \mathrm{a}-\mathbf{i}$ versus $0.3 \mu \mathrm{M}$ for APTO-253. Against the HL60 human acute promyeloid leukemia cell line, most of our tested phenanthrolines, $1 \mathbf{a}-\mathbf{i}$, showed an antiproliferative activity with $\mathrm{IC}_{50}$ values ranging from 3.0 to $8.0 \mu \mathrm{M}$, except $1 \mathrm{c}$ that was found inactive. Among derivatives $\mathbf{1 a - i}$, the phenanthrolines derivatives $1 \mathbf{g - i}$, bearing pyridinylpropylaminomethyl moieties, exhibited the best antiproliferative activity against the growth of human myeloid U937 cell line $\left(\mathrm{IC}_{50}\right.$ ranging from 2 to $\left.3 \mu \mathrm{M}\right)$ in comparison with their other analogs, $\mathbf{1 a}-\mathbf{c}$ and $\mathbf{1 d}-\mathbf{f}$, which were found less active $\left(\mathrm{IC}_{50}\right.$ ranging from 5 to $19 \mu \mathrm{M}$ for $1 \mathrm{a}-\mathrm{c}$ and $\mathrm{IC}_{50}$ ranging from 4 to $7.5 \mu \mathrm{M}$ for $1 \mathrm{~d}-\mathrm{f}$ ), but lower than that of the reference compound APTO-253 $\left(\mathrm{IC}_{50}<1 \mu \mathrm{M}\right)$. In addition, the cytotoxicity of each phenanthroline, 1a-i, was then evaluated against the HS27a stromal cell line to determine some index of selectivity (Tables 2 and 3 ). Thus, indexes of selectivity (IS) were defined as the ratio of the $\mathrm{IC}_{50}$ value against the HS27a stromal cell line to the $\mathrm{IC}_{50}$ value against the K562, KU812, MV4-11, HL60, and U937 cell lines (Table 3).

As expected, most of the phenanthrolines, 1a-i, showed a significant level of cytotoxicity against the HS27a stromal cell line with $\mathrm{IC}_{50}$ ranging from 3.4 to over $23.6 \mu \mathrm{M}$. Among them, we could notice that 2,9-bis[4-(pyridin-4-ylmethylaminomethyl)phenyl]-1,10- 


\begin{tabular}{|c|c|c|c|c|c|}
\hline \multirow[t]{2}{*}{ Compound } & \multicolumn{5}{|l|}{$\Delta T_{m}\left({ }^{\circ} \mathrm{C}\right)^{a}$} \\
\hline & Fc-MYCT & FK-RAST & FBcl-2T & F21T & FdxT \\
\hline PhenDC3 & $12.7 \pm 0.2$ & $17.9 \pm 0.2$ & $13.1 \pm 0.2$ & $22.1 \pm 0.2$ & $0.1 \pm 0.2$ \\
\hline $1 a$ & $1.1 \pm 0.1$ & $11.7 \pm 0.5$ & $3.8 \pm 0.2$ & $7.7 \pm 1.1$ & $-1.3 \pm 0.1$ \\
\hline $1 b$ & $0.1 \pm 0.2$ & $6.2 \pm 0.3$ & $2.9 \pm 0.3$ & $8.7 \pm 0.1$ & $-1.2 \pm 0.1$ \\
\hline $1 c$ & $4.3 \pm 0.3$ & $3.2 \pm 0.1$ & $2.8 \pm 0.4$ & $6.4 \pm 1.2$ & $-0.5 \pm 0.3$ \\
\hline $1 d$ & $3.0 \pm 1.3$ & $7.4 \pm 0.1$ & $4.6 \pm 1.0$ & $10.5 \pm 0.9$ & $-1.0 \pm 0.2$ \\
\hline $1 e$ & $2.0 \pm 0.7$ & $6.4 \pm 0.3$ & $3.8 \pm 0.1$ & $5.9 \pm 1.2$ & $-0.9 \pm 0.2$ \\
\hline $1 f$ & $3.2 \pm 1.1$ & $7.1 \pm 0.1$ & $3.8 \pm 0.5$ & $8.3 \pm 1.0$ & $-1.2 \pm 0.1$ \\
\hline $1 g$ & $7.7 \pm 1.3$ & $8.9 \pm 0.3$ & $6.8 \pm 0.6$ & $17.0 \pm 0.2$ & $0.2 \pm 0.1$ \\
\hline $1 \mathrm{~h}$ & $5.7 \pm 0.9$ & $11.2 \pm 0.2$ & $6.8 \pm 0.3$ & $16.5 \pm 0.4$ & $0.2 \pm 0.1$ \\
\hline $1 \mathrm{i}$ & $3.4 \pm 0.9$ & $12.4 \pm 0.6$ & $9.2 \pm 0.3$ & $17.9 \pm 0.6$ & $-0.7 \pm 0.1$ \\
\hline AРTO-253 & $1.0 \pm 0.1$ & $1.3 \pm 0.2$ & $0.5 \pm 0.1$ & $1.0 \pm 0.1$ & $0.2 \pm 0.1$ \\
\hline
\end{tabular}

TABLE 4 FRET melting values for the selected compounds, $1 \mathbf{a}-\mathbf{i}$, and APTO-253 with Fc-MYCT, FK-RAST, FBcl-2T, F21T, and $\mathrm{FdxT}$ in $\mathrm{K}^{+}$conditions at $2 \mu \mathrm{M}$

Note: PhenDC3 was tested at $0.5 \mu \mathrm{M}$. Error margins correspond to SD of three replicates.

Abbreviation: FRET, fluorescence resonance energy transfer.

${ }^{\mathrm{a}} \Delta T_{\mathrm{m}}$ values of Fc-MYCT, FK-RAST, FBcl-2T, F21T, and FdxT (0.2 $\left.\mu \mathrm{M}\right)$ were recorded in $10 \mathrm{mM}$ lithium cacodylate (pH 7.2), $10 \mathrm{mM} \mathrm{KCl,} 90 \mathrm{mM} \mathrm{LiCl}$.

phenanthroline $1 \mathrm{c}$ showed interesting selectivity toward $\mathrm{K} 562$, KU812, and MV4-11 cell lines ( $\mathrm{SI}=6.1,5.8$, and 7.9, respectively). Derivative 1c could now be considered a suitable candidate for further pharmacological studies. The reference compound APTO253 also showed interesting selectivity with an IS value of 13.3 against the MV4-11 cell line.

\section{3 | FRET melting experiments}

G4-forming motifs have been identified in oncogene promoter regions, bringing to light the therapeutic potential for targeted gene regulation at the transcriptional level. Among them, the most studied oncogene promoter G4s involve c-MYC, Bcl-2, h-Ras, K-RAS, and c-KIT. Thus, we evaluated ligand-induced stabilization, specificity, and selectivity of these newly synthesized phenanthrolines, $1 \mathbf{1 a}-\mathbf{i}$, for various oncogene promoter G4 topologies including c-MYC, BCL-2, and K-RAS through FRET melting experiments (Tables 4 and 5, exemplary melting curves in Figures S1-S4).

The stabilization of our compounds was also investigated against the fluorescently labeled human telomeric sequence F21T. To probe the G4 selectivity of our heterocyclic ligands 1 over duplex DNA, a FRET melting assay was performed using a duplex control sequence, FdxT. For comparison, we also evaluated the reference G4 ligand PhenDC3 and the antileukemial reference drug APTO-253. To enable comparison of selectivities, we calculated the difference $\left(\Delta T_{m}\right)$ between the $T_{m}$ of the G4 formed by c-MYC, Bcl-2, K-RAS, F21T, or FdxT in the presence or absence of each selected compound. These $\Delta T_{\mathrm{m}}$ values are presented in Table 4. For these substituted phenanthroline compounds, $1 \mathrm{a}-\mathbf{i}$, the $\Delta T_{\mathrm{m}}$ values ranged from $0.1^{\circ} \mathrm{C}$ to $17.9^{\circ} \mathrm{C}$ at $2 \mu \mathrm{M}$ ligand concentration.

The best nitrogen heterocyclic ligands that stabilize all the three proto-oncogenes (c-MYC, Bcl-2, K-RAS) and the human F21T G4 sequences were compounds $1 \mathrm{~g}-\mathbf{i}$, bearing pyridinylpropylaminomethyl side chains at position 4 of the benzyl rings (Table 4). We also noticed that 2,9-bis[4-(pyridin-2-ylmethylaminomethyl)phenyl]-1,10-phenanthroline 1a showed the same range of stabilization on the K-RAS telomeric G4 as those observed for compounds $1 \mathrm{~g}-\mathrm{i}$ with a $\Delta T_{\mathrm{m}}$ value of $11.7^{\circ} \mathrm{C}$ versus $8.9-12.4^{\circ} \mathrm{C}$ for $1 \mathrm{~g}-\mathbf{i}$. The radar plot shown in Figure 2 shows that compounds $\mathbf{1 g}-\mathbf{i}$ are able to stabilize most of all the G4-forming sequences.

As observed in Table 4, the stabilization effects on the different quadruplex sequences seem to be dependent on the length of the pyridinylalkylaminomethyl side chain of the phenanthrolines 1. For each G4 sequence, the substituted phenanthroline ligands $\mathbf{1 g}$-i bearing pyridinylpropylaminomethyl side chains exhibited the best and strong stabilization profile in comparison with their pyridinylethylaminomethyl or pyridinylmethylaminomethylsubstituted homologs $1 \mathbf{d}-\mathbf{f}$ and $1 \mathrm{a}-\mathrm{c}$, with the latter being the least stabilizing ligands. Concerning the position of the substitution of the pyridine group on the aminoalkyl chain, we cannot really conclude in terms of structure-activity relationships. In addition, compounds $1 \mathrm{a}-\mathbf{i}$ have higher affinities toward the K-RAS human oncogene promoter sequence as compared with c-MYC and $\mathrm{Bcl}-2$ ones. From a general point of view, all our ligands, 1a-i, were found to show lower stabilization than the reference PhenDC3 ligand. Surprisingly, by using FRET melting assays, the reference drug APTO-253 was found nearly ineffective to stabilize all the tested G4 sequences, even if this compound was previously described to stabilize the c-MYC G4 structure. ${ }^{[16]}$

In addition, we could also notice that phenanthrolines $1 \mathrm{~g}$-i were found more specific for the hybrid G4 topology of the F21T sequence $\left(16.5-17.9^{\circ} \mathrm{C}\right)$ than for the parallel G4 structures of c-MYC, Bcl-2, or K-RAS $\left(3.4-7.7^{\circ} \mathrm{C}\right.$ for C-MYC; $8.9-12.4^{\circ} \mathrm{C}$ for K-RAS, and $6.8-9.2^{\circ} \mathrm{C}$ for $\mathrm{Bcl}-2)$. 
TABLE 5 Labeled DNA sequences used in the present study

\begin{tabular}{|c|c|c|}
\hline Name & Sequences & Topology \\
\hline FK-RAST & FAM-AGGGCGGTGTGGGAAGAGGGA-TAMRA & Parallel \\
\hline $\mathrm{FBcl}-2 \mathrm{~T}$ & FAM-GGGCGCGGGAGGAAGGGGGCGGG-TAMRA & Parallel \\
\hline F21T & FAM-GGGTTAGGGTTAGGGTTAGGG-TAMRA & Hybrid \\
\hline Fc-MYCT & FAM-GGGTGGGTAGGGTGGGTAA-TAMRA & Parallel \\
\hline FdxT & FAM-TATAGCTATA-hexaethylene glycol-TATAGCTATA-TAMRA & Hairpin duplex \\
\hline
\end{tabular}

Note: All sequences are provided in the $5^{\prime}$ to $3^{\prime}$ direction.

FRET assays showed that there was no binding to duplex DNA sequence.

\subsection{Detection of telomerase activity in cell lysates}

As the human telomeric motif F21T was among the most stabilized G4 sequences (Table 4), we decided to investigate whether our more active phenanthrolines $\mathbf{1 g}$-i may interfere with canonical telomeric functions. For this reason, we assayed their impact on telomerase activity. Telomerase activity in HuT78 and MV4-11 protein extracts was investigated in the presence of $0-5 \mu \mathrm{M}$ of the ligands (Figure $3 a-c)$.

As expected at $0 \mu \mathrm{M}$, telomerase activity was detectable in both cell lines. The value at $0 \mu \mathrm{M}$ was arbitrarily considered for $100 \%$ telomerase activity. All our three phenanthrolines, $1 \mathbf{g}-\mathbf{i}$, practically inhibited telomerase activity at $5 \mu \mathrm{M}$ for HuT78 and MV4-11 cell lines. However, at $5 \mu \mathrm{M}, 1 \mathrm{i}$ seems to be the more bioactive compound to abolish most of the telomerase activity (>95\%) in both leukemic cell lines. Although telomerase activity was detected when tested at $0.5,1$, and $2 \mu \mathrm{M}$ of $1 \mathrm{~g}-\mathbf{i}$, an $80 \%$ decrease was observed at $2 \mu \mathrm{M}$ for the three tested phenanthrolines, $\mathbf{1} \mathbf{g}-\mathbf{i}$, in both cell lines. (a)

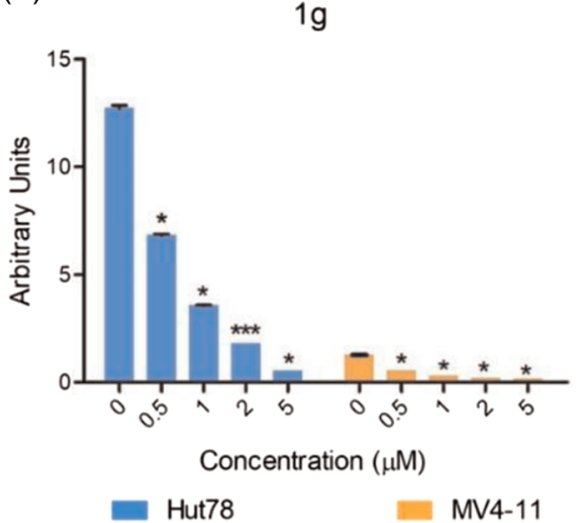

(b)

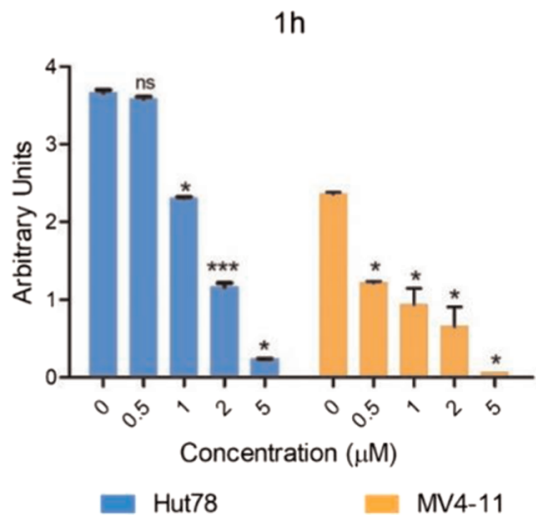

(c)

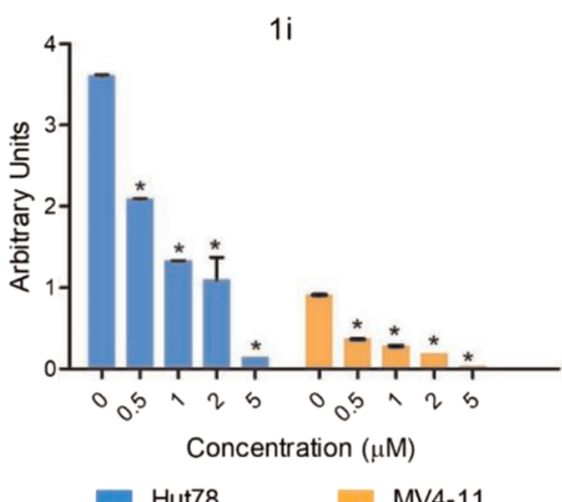

FIGURE 3 Telomerase activity in HuT78 and MV-4-11 cell lysates was investigated in the presence of 0-5 $\mu \mathrm{M}$ of $1 \mathrm{~g}$ (a), $1 \mathrm{~h}$ (b), and 1i ligands (c). The $p$ values calculated from Mann-Whitney tests are as follows: ns, not significant, ${ }^{*} p \leq .05,{ }^{* * *} p<.001$ 


\begin{tabular}{|c|c|c|c|c|}
\hline Name & Sequences & Topology in $1 \mathrm{mM} \mathrm{KCl}$ & PDB & References \\
\hline K-RAS & AGGGCGGTGTGGGAAGAGGGA & Unfolded ssDNA & & \\
\hline $\mathrm{BCl}-2$ & GGGCGCGGGAGGAAGGGGGCGGG & Hybrid quadruplex & $2 \mathrm{~F} 8 \mathrm{U}^{\mathrm{a}}$ & [28] \\
\hline 24TTG & TTGGGTTAGGGTTAGGGTTAGGGA & Hybrid quadruplex & 2GKU & [29] \\
\hline c-MYC & TGAGGGTGGGTAGGGTGGGTAA & Parallel quadruplex & 1XAV & [30] \\
\hline ds26 & CAATCGGATCGAATTCGATCCGATTG & B-dsDNA & & \\
\hline
\end{tabular}

TABLE 6 DNA oligonucleotides used in native mass spectrometry experiments

Note: All sequences are provided in the $5^{\prime}$ to $3^{\prime}$ direction.

Abbreviations: dsDNA, double-stranded DNA; ssDNA, single-stranded DNA.

${ }^{\mathrm{a}}$ The bcl2MidG4 sequence variant has been used.

\section{5 | Native electrospray mass spectrometry}

Native mass spectrometry experiments were carried out to characterize the affinity and stoichiometry of binding of $1 \mathrm{~d}, 1 \mathrm{~g}, 1 \mathrm{~h}$, and $1 \mathrm{i}$ to G4 forming oligonucleotides, and their selectivity against unfolded and double-stranded DNA (Figures S1-S5).

The samples were prepared in trimethylammonium acetate (TMAA)-buffered solutions, supplemented with $1 \mathrm{mM} \mathrm{KCl}$, to allow the formation of $\mathrm{G} 4 \mathrm{~s}$ with the biologically relevant $\mathrm{K}^{+} \mathrm{ca}-$ tion. ${ }^{[27]}$ The sequences are similar to those used in the FRET melting experiment, yet the conformers formed in solution might differ owing to the lower potassium concentration and the absence of fluorophore labeling (Table 6). The topologies were, therefore, characterized by circular dichroism in the mass spectrometry conditions (Figures S5-S9). c-MYC folds into a parallel quadruplex (positive band at $260 \mathrm{~nm}$ and negative band at $240 \mathrm{~nm}$ ) and 24TTG, a 24-mer variant of the human telomeric sequence, into a hybrid topology (positive band at $290 \mathrm{~nm}$ and shoulder at $270 \mathrm{~nm}$ ). Both adopt the same structure in $1 \mathrm{mM} \mathrm{KCl}$ as their PDB-deposited structures (obtained at higher $\mathrm{KCl}$ concentrations) ${ }^{[31,32]}$ and have a similar profile as the FC-MYCT and F21T oligonucleotides from the FRET panel. The particular variant of $\mathrm{BCl}-2$ used here (the same as in the FRET panel) can form a mixture of hybrid conformers, ${ }^{[28]}$ which are almost entirely folded in $1 \mathrm{mM} \mathrm{KCl}$ (positive bands at 260 and $290 \mathrm{~nm}$ ). Finally, we found that the K-RAS oligonucleotide is almost entirely unfolded in $1 \mathrm{mM} \mathrm{KCl}$ solution, as evidenced by the absence of specific potassium cation binding and CD profile (weak band at $260 \mathrm{~nm}$ ), which was confirmed by UV melting experiments
(Figure S10). It was, therefore, used as a G-rich, unfolded, singlestranded control. The selectivity against duplex DNA was assessed by including the auto-complementary ds 26 sequence in the panel.

All four ligands bind moderately, and remarkably similar to 24TTG with a 1:1 stoichiometry $\left(p K_{d 1}=4.6\right.$; Table 7). A weaker second binding site was observed $\left(p K_{d 2}=3.6-4.0\right)$, with no apparent binding cooperativity $\left(K_{\mathrm{d} 1} / K_{\mathrm{d} 2}=0.12-0.27\right)$. The same affinity range was found for $1 \mathrm{~g}-\mathrm{i}$ binding to $\mathrm{BCl}-2\left(\mathrm{pK}_{\mathrm{d} 1}=4.5\right)$, with the second binding site being very weakly bound $\left(\mathrm{p} K_{\mathrm{d} 2}=3.2-3.5, K_{\mathrm{d} 1} / K_{\mathrm{d} 2} \leq 0.1\right)$. $1 d$, which has shorter side chains, has a significantly lower affinity $\left(\mathrm{p} K_{\mathrm{d} 1}=4.0\right)$, and no second binding site was observed.

Much larger affinities were found for c-MYC binding by $1 \mathrm{~h}$ and $1 \mathrm{i}\left(\mathrm{p} K_{\mathrm{d} 1}=5.5\right.$ and 5.0$)$, and to a lower extent by $1 \mathrm{~g}\left(\mathrm{p} K_{\mathrm{d} 1}=4.7\right)$. Here again, the shorter side chains of $1 \mathrm{~d}$ are detrimental to binding $\left(\mathrm{p} K_{\mathrm{d} 1}=4.4\right)$. In addition, $\mathrm{c}-\mathrm{MYC}$ is bound by a second ligand in all cases. These secondary binding sites are weakly bound by $1 \mathrm{i}$ and $1 \mathrm{~g}$ $\left(\mathrm{p} K_{\mathrm{d} 2}=3.9\right.$ and $\left.3.5 ; K_{\mathrm{d} 1} / K_{\mathrm{d} 2}<0.1\right)$, and they remain virtually unbound by $1 \mathrm{~d}\left(\mathrm{p} K_{\mathrm{d} 2}=3.0 ; K_{\mathrm{d} 1} / K_{\mathrm{d} 2}=0.04\right)$. Similar to the first binding site, $1 \mathrm{~h}$ binds better than its counterparts to this secondary site, by an order of magnitude; however, this remains a non-cooperative process $\left(\mathrm{p} K_{\mathrm{d} 2}=4.6 ; K_{\mathrm{d} 1} / K_{\mathrm{d} 2}=0.13\right)$.

The unfolded form of K-RAS (i.e., not binding $\mathrm{K}^{+}$) is unbound by all ligands, indicating that they do not bind unfolded ssDNA. However, ligand $1 \mathrm{~h}$ binds a small amount of this sequence folded into a quadruplex (i.e., binding specifically $2 \mathrm{~K}^{+}$), which was present in the solution initially and/or by promoting its formation. However, as the amount of formed G4 is not known, this precludes determining the affinity constant for the folded KRAS G4. The apparent $p K_{d}$

TABLE 7 Binding affinities of the $1: 1\left(\mathrm{p} K_{\mathrm{d} 1}\right)$ and 2:1 $\left(\mathrm{p} K_{\mathrm{d} 2}\right)$ complexes, and binding cooperativities $\left(K_{\mathrm{d} 1} / K_{\mathrm{d} 2}\right)^{a}$, of $1 \mathrm{~d}$ and $1 \mathrm{~g}-\mathbf{i}$ ligands with 24TTG, BCl-2, c-MYC, K-RAS in $100 \mathrm{mM}$ TMAA and $1 \mathrm{mM} \mathrm{KCl}$, determined by native MS

\begin{tabular}{|c|c|c|c|c|c|c|c|c|c|c|c|c|c|c|c|c|}
\hline & 24TTC & & & & $\mathrm{BCl}-$ & & & & c-MY & & & & ds26 & & & \\
\hline $\mathrm{p} K_{\mathrm{d} 1}$ & 4.6 & 4.6 & 4.6 & 4.6 & 4.0 & 4.5 & 4.5 & 4.5 & 4.4 & 4.7 & 5.5 & 5.0 & n.b. & n.b. & n.b. & n.b. \\
\hline $\mathrm{p} K_{\mathrm{d} 2}$ & 3.9 & 4.0 & 4.0 & 3.6 & n.b & 3.2 & 3.5 & 3.3 & 3.0 & 3.5 & 4.6 & 3.9 & n.b. & n.b. & n.b. & n.b. \\
\hline$K_{\mathrm{d} 1} / K_{\mathrm{d} 2}$ & 0.20 & 0.27 & 0.27 & 0.12 & n.a & 0.05 & 0.10 & 0.07 & 0.04 & 0.07 & 0.13 & 0.08 & n.a. & n.a. & n.a. & n.a. \\
\hline
\end{tabular}

Abbreviations: MS, mass spectrometry; TMAA, trimethylammonium acetate.

an.a., not applicable; n.b., no observed binding. 

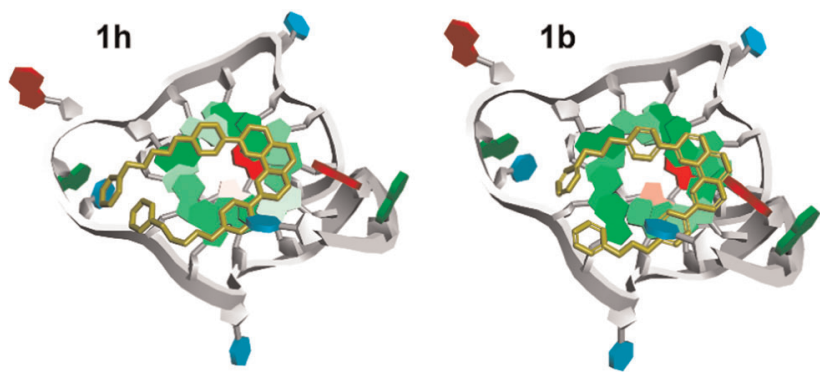

FIGURE 4 Comparative docking of ligands $1 \mathrm{~h}$ and $\mathbf{1 b}$ on the c-myc G-quadruplex extracted from PDB structure $2 \mathrm{MGN}^{[33]}$

obtained is the convolution of the folding equilibrium (displaced mainly toward the unfolded form) and the binding equilibrium. For this reason, it cannot be compared directly with the $\mathrm{p} K_{\mathrm{d}}$ values obtained for the three other G4s. Finally, no complex was observed on ds26, confirming that this set of ligands does not bind to dsDNA.

Overall, ligands $1 \mathrm{~g}-\mathbf{i}$ share similar binding behaviors, that is, (i) no binding to ss- and ds-DNA, (ii) moderate binding to the hybrid quadruplexes formed by 24TTG and $\mathrm{BCl}-2$, (iii) stronger binding to the parallel c-MYC quadruplex, and (iv) weak binding to secondary binding sites. Ligand $1 \mathbf{d}$, which has shorter side chains, has worse affinities for $\mathrm{BCl}-2$ and $\mathrm{c}-\mathrm{MYC}$ than its counterparts, in line with the FRET melting results. This could be explained by a lesser ability to form electrostatic interactions with loop or groove phosphates for some topologies, but not all (24TTG is a counterexample). Ligand $1 \mathrm{~h}$ displays the strongest binding for all tested quadruplexes and is capable of folding small amounts of, and/or promoting the folding of, the K-RAS G4.

\subsection{Docking}

Ligands with the longer arms (1g-i) have the highest affinity for the G4s. To visualize where this arm length places the pyridinyl groups, we carried out docking with a parallel c-myc G4. The structure of the complex between the oligonucleotide dTGAGGGTGGTGAGgGTGGGGAAGG and PhenDC3 (PDB code: $2 \mathrm{MGN})^{[33]}$ was used as the starting point. Ligands $1 \mathrm{~h}$ (long arms) and 1b (short arms control) were constructed and optimized using the AMBER ParmBSCO force field. ${ }^{[34]}$ Three different conformers of $1 \mathrm{~h}$ and $1 \mathrm{~b}$ were tested and energy-ranked (Figures S11 and S12). The PhenDC3 ligand on the 2MGN structure was then replaced with $1 \mathrm{~h}$ or $1 \mathrm{~b}$, and the geometry was further optimized until a gradient of $0.05 \mathrm{kcal} / \mathrm{mol}$ was reached, and then it was subjected to 2 ns molecular dynamics. HyperChem 8.0.10 (Hypercube Inc.) was used for the calculations. The figures were generated using Biovia Discovery Studio Visualizer (Dassault Systèmes). Figure 4 , showing the lowest energy conformers of $1 \mathrm{~h}$ and $\mathbf{1 b}$ stacked on the terminal quartet, reveals that in the most affine ligand (1h), the pyridinyl groups dangle in the groove.

\section{3 | CONCLUSION}

In this study, we have designed and synthesized a series of nine new 2,9-bis[4-(pyridinylalkylaminomethyl)phenyl]-1,10-phenanthroline derivatives, $1 \mathrm{a}-\mathbf{i}$, and evaluated their antileukemic activity against five human leukemic cell lines, K562, KU812, MV4-11, HL60, and U937. Their cytotoxicity against the HS27a stromal cell line was also evaluated. Their ability to stabilize various oncogene promoter G4 structures (c-MYC, BCL-2, and k-RAS) has been also determined through the FRET melting assay and native mass spectrometry. By using these pharmacological and biophysical results, preliminary SAR studies on these phenanthroline compounds have been discussed. The biological evaluations of new derivatives $1 \mathbf{a}-\mathbf{i}$ showed cytotoxic activity against the different myeloid and lymphoid leukemia cell lines. The disubstituted pyridinylpropylaminomethyl phenanthrolines $1 \mathrm{~g}$-i showed the more interesting antileukemic activities and may be now involved in further pharmacological modulations and investigations. The inhibition for telomerase activity by the more active ligands was assessed through telomeric repeat amplification protocol (TRAP) assay, and the result showed a significant inhibition at $5 \mu \mathrm{M}$ concentration for ligand 1i. Moreover, further investigations are required to reveal the complete mechanism of action of these bioactive phenanthrolines.

\section{EXPERIMENTAL}

\section{1 | Chemistry}

\subsection{1 | General}

Commercially available reagents were used as received without additional purification. The reference drug APTO-253 (free base) was provided from CliniSciences. Melting points were determined with an SM-LUX-POL Leitz hot-stage microscope and were uncorrected. Infrared (IR) spectra were recorded on a NICOLET 380FT-IR spectrophotometer. Nuclear magnetic resonance (NMR) spectra were recorded with tetramethylsilane as an internal standard using a Bruker Avance 300 spectrometer. Splitting patterns have been reported as follows: s, singlet; bs, broad singlet; $d$, doublet; $t$, triplet; q, quartet; dd, double doublet; ddd, double double doublet; qt, quintuplet; m, multiplet. Analytical thin-layer chromatography was carried out on $0.25 \mathrm{~mm}$ precoated silica gel plates (POLYGRAM SIL G/UV254) and visualization of compounds was done after UV light irradiation. Silica gel 60 (70-230 mesh) was used for column chromatography. Mass spectra were recorded on an ESI LTQ Orbitrap Velos mass spectrometer (Thermo Fisher Scientific). Ionization was performed using an electrospray ion source operating in a positive ion mode with a capillary voltage of $3.80 \mathrm{kV}$ and capillary temperature of $250^{\circ} \mathrm{C}$. The scan type analyzed was full scan, and all mass spectrometry (MS) recordings were in the $\mathrm{m} / \mathrm{z}$ range between 150 and $2000 \mathrm{~m} / \mathrm{z}$. Fragmentation of no type was performed, and the resolution used for the analysis was 60.000 . 
Archiv der Pharmazie

The InChl codes of the investigated compounds, together with some biological activity data, are provided as Supporting Information.

4.1.2 | General procedure for the synthesis of 2,9-bis[4-(pyridinylalkyliminomethyl)phenyl]-1,10phenanthrolines $4 \mathbf{a}-\mathbf{i}$

The bis-[2,9-(formylphenyl)]-1,10-phenanthroline 3 (150 mg, 0.386 mmol) was dissolved in $6 \mathrm{ml}$ of toluene. Activated molecular sieves $4 \AA$ ( $800 \mathrm{mg}$ ) and then pyridinylalkylamine $(0.812 \mathrm{mmol})$ were introduced in the latter solution. The reaction mixture was stirred in a stoppered flask for $24 \mathrm{~h}$. The suspension that was obtained was filtered and washed with dichloromethane. Then, the solvent was removed under reduced pressure to afford diimine 4 as an oil.

\section{2,9-Bis[4-(pyridin-2-ylmethyliminomethyl)phenyl]-1,10-}

phenanthroline $(4 a)$

Yellow oil (yield, 98\%). ${ }^{1} \mathrm{H}$ NMR $\left(\mathrm{CDCl}_{3}\right) \delta$ ppm: $8.62\left(\mathrm{~m}, 4 \mathrm{H}, 2 \mathrm{H}-6_{\mathrm{pyr}}\right.$ and $2 \mathrm{CH}=\mathrm{N}), 8.57\left(\mathrm{~d}, 4 \mathrm{H}, J=8.40 \mathrm{~Hz}, 2 \mathrm{H}-2^{\prime}\right.$ and $\left.2 \mathrm{H}-6{ }^{\prime}\right), 8.35(\mathrm{~d}, 2 \mathrm{H}$, $J=8.40 \mathrm{~Hz}, \mathrm{H}-4$ and $\mathrm{H}-7$ ), $8.21(\mathrm{~d}, 2 \mathrm{H}, J=8.40 \mathrm{~Hz}, \mathrm{H}-3$ and $\mathrm{H}-8), 8.06$ (d, $4 \mathrm{H}, J=8.40 \mathrm{~Hz}, 2 \mathrm{H}-3^{\prime}$ and $2 \mathrm{H}-5$ ), 7.82 (s, 2H, H-5 and H-6), 7.73 (ddd, $2 \mathrm{H}, J=7.80,7.20$ and $1.80 \mathrm{~Hz}, 2 \mathrm{H}-4_{\text {pyr }}$ ), 7.52 (ddd, $2 \mathrm{H}, J=7.20$, 0.90 and $0.90 \mathrm{~Hz}, 2 \mathrm{H}-3_{\text {pyr }}$ ), 7.22 (ddd, $2 \mathrm{H}, J=7.80,6.00$ and $0.90 \mathrm{~Hz}$, $\left.2 \mathrm{H}-5_{\text {pyr }}\right), 5.05$ (s, $4 \mathrm{H}, 2 \mathrm{NCH}_{2}$ ).

\section{2,9-Bis[4-(pyridin-3-ylmethyliminomethyl)phenyl]-1,10-}

phenanthroline $(4 b)$

Yellow crystals (yield, 98\%); m.p. $=195-197^{\circ} \mathrm{C} .{ }^{1} \mathrm{H} \mathrm{NMR}\left(\mathrm{CDCl}_{3}\right) \delta$ ppm: 8.67 (ddd, $2 \mathrm{H}, J=1.90,0.80$ and $0.80 \mathrm{~Hz}, 2 \mathrm{H}-2_{\text {pyr }}$ ), $8.56-8.53$ $\left(\mathrm{m}, 8 \mathrm{H}, 2 \mathrm{H}-2^{\prime}, 2 \mathrm{H}-6^{\prime}, 2 \mathrm{H}-6_{\mathrm{pyr}}\right.$ and $\left.2 \mathrm{CH}=\mathrm{N}\right), 8.29(\mathrm{~d}, 2 \mathrm{H}, J=8.40 \mathrm{~Hz}$, $\mathrm{H}-4$ and $\mathrm{H}-7), 8.16(\mathrm{~d}, 2 \mathrm{H}, J=8.40 \mathrm{~Hz}, \mathrm{H}-3$ and $\mathrm{H}-8), 8.00(\mathrm{~d}, 4 \mathrm{H}$, $J=8.40 \mathrm{~Hz}, 2 \mathrm{H}-3^{\prime}$ and $2 \mathrm{H}-5$ ), 7.77 (s, $2 \mathrm{H}, \mathrm{H}-5$ and $\mathrm{H}-6$ ), 7.73 (ddd, $2 \mathrm{H}, J=7.65,1.90$ and $1.90 \mathrm{~Hz}, 2 \mathrm{H}-4_{\text {pyr }}$ ), 7.31 (ddd, $2 \mathrm{H}, J=7.65,5.40$ and $0.80 \mathrm{~Hz}, 2 \mathrm{H}-5_{\text {pyr }}$ ), $4.88\left(\mathrm{~s}, 4 \mathrm{H}, 2 \mathrm{NCH}_{2}\right)$.

\section{2,9-Bis[4-(pyridin-4-ylmethyliminomethyl)phenyl]-1,10-}

phenanthroline $(4 c)$

Beige crystals (yield, 98\%); m.p. $=235-237^{\circ} \mathrm{C} .{ }^{1} \mathrm{H} \mathrm{NMR}\left(\mathrm{CDCl}_{3}\right) \delta$ ppm: 8.62 (dd, $4 \mathrm{H}, J=6.00$ and $1.50 \mathrm{~Hz}, 2 \mathrm{H}-2_{\text {pyr }}$ and $2 \mathrm{H}-6_{\text {pyr }}$ ), 8.58 (d, $4 \mathrm{H}, J=8.40 \mathrm{~Hz}, 2 \mathrm{H}-2^{\prime}$ and $\left.2 \mathrm{H}-6\right), 8.55(\mathrm{~s}, 2 \mathrm{H}, 2 \mathrm{CH}=\mathrm{N}), 8.36(\mathrm{~d}, 2 \mathrm{H}$, $J=8.40 \mathrm{~Hz}, \mathrm{H}-4$ and $\mathrm{H}-7), 8.21(\mathrm{~d}, 2 \mathrm{H}, J=8.40 \mathrm{~Hz}, \mathrm{H}-3$ and $\mathrm{H}-8), 8.04$ (d, $4 \mathrm{H}, J=8.40 \mathrm{~Hz}, 2 \mathrm{H}-3^{\prime}$ and $2 \mathrm{H}-5$ ), 7.84 (s, 2H, H-5 and $\mathrm{H}-6$ ), 7.37 (dd, $4 \mathrm{H}, J=6.00$ and $1.50 \mathrm{~Hz}, 2 \mathrm{H}-3_{\text {pyr }}$ and $2 \mathrm{H}-5_{\text {pyr }}$ ), 4.89 (s, $4 \mathrm{H}$, $2 \mathrm{NCH}_{2}$ ).

\section{2,9-Bis[4-(pyridin-2-ylethyliminomethyl)phenyl]-1,10-}

phenanthroline $(4 d)$

Yellow crystals (yield, 98\%); m.p. $=166-168^{\circ} \mathrm{C} .{ }^{1} \mathrm{H} \mathrm{NMR}\left(\mathrm{CDCl}_{3}\right) \delta$ ppm: 8.59 (ddd, $2 \mathrm{H}, J=6.00,1.80$ and $0.90 \mathrm{~Hz}, 2 \mathrm{H}-6_{\text {pyr }}$ ), 8.50 (d, $4 \mathrm{H}$, $J=8.40 \mathrm{~Hz}, 2 \mathrm{H}-2^{\prime}$ and $\left.2 \mathrm{H}-6\right), 8.31(\mathrm{~s}, 2 \mathrm{H}, 2 \mathrm{CH}=\mathrm{N}), 8.27(\mathrm{~d}, 2 \mathrm{H}$, $J=8.40 \mathrm{~Hz}, \mathrm{H}-4$ and $\mathrm{H}-7$ ), $8.13(\mathrm{~d}, 2 \mathrm{H}, J=8.40 \mathrm{~Hz}, \mathrm{H}-3$ and $\mathrm{H}-8), 7.90$ (d, $4 \mathrm{H}, J=8.40 \mathrm{~Hz}, 2 \mathrm{H}-3^{\prime}$ and $2 \mathrm{H}-5$ ), 7.75 (s, 2H, H-5 and H-6), 7.58 (ddd, $2 \mathrm{H}, J=7.80,7.20$ and $1.80 \mathrm{~Hz}, 2 \mathrm{H}-4_{\text {pyr }}$ ), 7.22 (ddd, $2 \mathrm{H}, J=7.20$, 0.90 and $0.90 \mathrm{~Hz}, 2 \mathrm{H}-3_{\text {pyr }}$ ), 7.11 (ddd, $2 \mathrm{H}, J=7.80,6.00$ and $0.90 \mathrm{~Hz}$, $2 \mathrm{H}-5_{\text {pyr }}$ ), 4.09 (t, $4 \mathrm{H}, J=7.20 \mathrm{~Hz}, 2 \mathrm{NCH}_{2}$ ), 3.26 (t, $4 \mathrm{H}, J=7.20 \mathrm{~Hz}$, $\left.2 \mathrm{CH}_{2} \mathrm{Pyr}\right)$.

\section{2,9-Bis[4-(pyridin-3-ylethyliminomethyl)phenyl]-1,10-} phenanthroline (4e)

Pale-yellow oil (yield, 98\%). ${ }^{1} \mathrm{H}$ NMR $\left(\mathrm{CDCl}_{3}\right) \delta$ ppm: 8.57 (ddd, $2 \mathrm{H}$, $J=1.90,0.90$ and $\left.0.90 \mathrm{~Hz}, 2 \mathrm{H}-2_{\text {pyr }}\right), 8.53\left(\mathrm{~d}, 2 \mathrm{H}, J=8.40 \mathrm{~Hz}, 2 \mathrm{H}-2^{\prime}\right.$ and $2 \mathrm{H}-6$ ), 8.49 (dd, $2 \mathrm{H}, J=5.90$ and $1.50 \mathrm{~Hz}, 2 \mathrm{H}-6_{\text {pyr }}$ ), 8.33 (d, $2 \mathrm{H}$, $J=8.40 \mathrm{~Hz}, \mathrm{H}-4$ and $\mathrm{H}-7), 8.29(\mathrm{~s}, 2 \mathrm{H}, 2 \mathrm{CH}=\mathrm{N}), 8.18(\mathrm{~d}, 2 \mathrm{H}$, $J=8.40 \mathrm{~Hz}, \mathrm{H}-3$ and $\mathrm{H}-8), 7.93\left(\mathrm{~d}, 4 \mathrm{H}, J=8.40 \mathrm{~Hz}, 2 \mathrm{H}-3^{\prime}\right.$ and $\left.2 \mathrm{H}-5^{\prime}\right)$, 7.81 (s, 2H, $\mathrm{H}-5$ and $\mathrm{H}-6$ ), 7.59 (ddd, $2 \mathrm{H}, J=7.80,1.80$ and $1.80 \mathrm{~Hz}$, $2 \mathrm{H}-4_{\text {pyr }}$ ), 7.24 (ddd, $2 \mathrm{H}, J=7.80,5.90$ and $0.90 \mathrm{~Hz}, 2 \mathrm{H}-5_{\text {pyr }}$ ), 3.94 (t, $4 \mathrm{H}, J=7.05 \mathrm{~Hz}, 2 \mathrm{NCH}_{2}$ ), 3.10 (t, $4 \mathrm{H}, J=7.05 \mathrm{~Hz}, 2 \mathrm{CH}_{2} \mathrm{Pyr}$ ).

\section{2,9-Bis[4-(pyridin-4-ylethyliminomethyl)phenyl]-1,10- phenanthroline (4f)}

Pale-yellow crystals (yield, 97\%); m.p. $=160-162^{\circ} \mathrm{C} .{ }^{1} \mathrm{H} \mathrm{NMR}\left(\mathrm{CDCl}_{3}\right) \delta$ ppm: 8.56 (dd, $4 \mathrm{H}, J=6.00$ and $1.50 \mathrm{~Hz}, 2 \mathrm{H}-2_{\text {pyr }}$ and $\left.2 \mathrm{H}-6_{\text {pyr }}\right), 8.53(\mathrm{~d}, 4 \mathrm{H}$, $J=8.40 \mathrm{~Hz}, 2 \mathrm{H}-2^{\prime}$ and $\left.2 \mathrm{H}-6\right), 8.36(\mathrm{~d}, 2 \mathrm{H}, J=8.55 \mathrm{~Hz}, \mathrm{H}-4$ and $\mathrm{H}-7), 8.29$ (s, $2 \mathrm{H}, 2 \mathrm{CH}=\mathrm{N}$ ), 8.21 (d, $2 \mathrm{H}, J=8.55 \mathrm{~Hz}, \mathrm{H}-3$ and $\mathrm{H}-8$ ), 7.94 (d, $4 \mathrm{H}$, $J=8.40 \mathrm{~Hz}, 2 \mathrm{H}-3^{\prime}$ and $2 \mathrm{H}-5$ ), $7.84(\mathrm{~s}, 2 \mathrm{H}, \mathrm{H}-5$ and $\mathrm{H}-6$ ), 7.23 (dd, $4 \mathrm{H}$, $J=6.00$ and $1.50 \mathrm{~Hz}, 2 \mathrm{H}-3_{\text {pyr }}$ and $\left.2 \mathrm{H}-5_{\text {pyr }}\right), 3.96(\mathrm{t}, 4 \mathrm{H}, J=6.90 \mathrm{~Hz}$, $2 \mathrm{NCH}_{2}$ ), 3.10 (t, $4 \mathrm{H}, J=6.90 \mathrm{~Hz}, 2 \mathrm{CH}_{2} \mathrm{Pyr}$ ).

\section{2,9-Bis[4-(pyridin-2-ylpropyliminomethyl)phenyl]-1,10- phenanthroline (4g)}

Yellow crystals (yield, 93\%); m.p. $=153-155^{\circ} \mathrm{C} .{ }^{1} \mathrm{H} \mathrm{NMR}\left(\mathrm{CDCl}_{3}\right) \delta \mathrm{ppm}$ : 8.52 (ddd, $2 \mathrm{H}, J=6.10,1.80$ and $\left.0.90 \mathrm{~Hz}, 2 \mathrm{H}-6_{\text {pyr }}\right), 8.49$ (d, $4 \mathrm{H}$, $J=8.40 \mathrm{~Hz}, 2 \mathrm{H}-2^{\prime}$ and $\left.2 \mathrm{H}-6\right), 8.35(\mathrm{~s}, 2 \mathrm{H}, 2 \mathrm{CH}=\mathrm{N}), 8.20(\mathrm{~d}, 2 \mathrm{H}$, $J=8.40 \mathrm{~Hz}, \mathrm{H}-4$ and $\mathrm{H}-7$ ), 8.08 (d, $2 \mathrm{H}, J=8.40 \mathrm{~Hz}, \mathrm{H}-3$ and $\mathrm{H}-8$ ), 7.92 (d, $4 \mathrm{H}, J=8.40 \mathrm{~Hz}, 2 \mathrm{H}-3^{\prime}$ and $2 \mathrm{H}-5$ ), 7.67 (s, $2 \mathrm{H}, \mathrm{H}-5$ and $\mathrm{H}-6$ ), 7.55 (ddd, $2 \mathrm{H}, J=7.80,7.20$ and $1.80 \mathrm{~Hz}, 2 \mathrm{H}-4_{\text {pyr }}$ ), 7.16 (ddd, $2 \mathrm{H}, J=7.20,0.90$ and $\left.0.90 \mathrm{~Hz}, 2 \mathrm{H}-3_{\text {pyr }}\right), 7.06$ (ddd, $2 \mathrm{H}, J=7.80,6.10$ and $0.90 \mathrm{~Hz}, 2 \mathrm{H}-5_{\text {pyr }}$ ), 3.71 (t, $4 \mathrm{H}, J=6.90 \mathrm{~Hz}, 2 \mathrm{NCH}_{2}$ ), 2.92 (t, $4 \mathrm{H}, J=6.90 \mathrm{~Hz}, 2 \mathrm{CH}_{2} \mathrm{Pyr}$ ), 2.19 (qt, $4 \mathrm{H}, J=6.90 \mathrm{~Hz}, 2 \mathrm{CH}_{2}$ ).

\section{2,9-Bis[4-(pyridin-3-ylpropyliminomethyl)phenyl]-1,10-}

phenanthroline (4h)

Yellow oil (yield, 98\%). ${ }^{1} \mathrm{H}$ NMR $\left(\mathrm{CDCl}_{3}\right) \delta$ ppm: 8.55-8.51 (m, 6H, $2 \mathrm{H}$ $2_{\text {pyr }}, 2 \mathrm{H}-2^{\prime}$ and $2 \mathrm{H}-6$ ), 8.45 (dd, $2 \mathrm{H}, J=5.70$ and $1.20 \mathrm{~Hz}, 2 \mathrm{H}-6_{\text {pyr }}$ ), 8.34 (s, $2 \mathrm{H}, 2 \mathrm{CH}=\mathrm{N}$ ), $8.18(\mathrm{~d}, 2 \mathrm{H}, J=8.40 \mathrm{~Hz}, \mathrm{H}-4$ and $\mathrm{H}-7), 8.07(\mathrm{~d}, 2 \mathrm{H}$, $J=8.40 \mathrm{~Hz}, \mathrm{H}-3$ and $\mathrm{H}-8), 7.94\left(\mathrm{~d}, 4 \mathrm{H}, J=8.10 \mathrm{~Hz}, 2 \mathrm{H}-3^{\prime}\right.$ and $\left.2 \mathrm{H}-5\right), 7.66$ (s, $2 \mathrm{H}, \mathrm{H}-5$ and $\mathrm{H}-6$ ), 7.51 (ddd, $2 \mathrm{H}, J=7.70,1.80$ and $1.80 \mathrm{~Hz}, 2 \mathrm{H}-4_{\text {pyr }}$ ), $7.25-7.20$ (m, $2 \mathrm{H}, 2 \mathrm{H}-5_{\text {pyr }}$ ), $3.66\left(\mathrm{t}, 4 \mathrm{H}, J=7.10 \mathrm{~Hz}, 2 \mathrm{NCH}_{2}\right), 2.73(\mathrm{t}, 4 \mathrm{H}$, $J=7.10 \mathrm{~Hz}, 2 \mathrm{CH}_{2} \mathrm{Pyr}$ ), 2.07 (qt, $4 \mathrm{H}, J=7.10 \mathrm{~Hz}, 2 \mathrm{CH}_{2}$ ).

\section{2,9-Bis[4-(pyridin-4-ylpropyliminomethyl)phenyl]-1,10- \\ phenanthroline (4i)}

Yellow oil (yield, 98\%). ${ }^{1} \mathrm{H}$ NMR $\left(\mathrm{CDCl}_{3}\right) \delta$ ppm: 8.53 (dd, $4 \mathrm{H}, J=6.00$ and $1.50 \mathrm{~Hz}, 2 \mathrm{H}-2_{\text {pyr }}$ and $\left.2 \mathrm{H}-6_{\text {pyr }}\right), 8.49\left(\mathrm{~d}, 4 \mathrm{H}, J=8.40 \mathrm{~Hz}, 2 \mathrm{H}-2^{\prime}\right.$ and $2 \mathrm{H}-6), 8.34(\mathrm{~s}, 2 \mathrm{H}, 2 \mathrm{CH}=\mathrm{N}), 8.26(\mathrm{~d}, 2 \mathrm{H}, J=8.55 \mathrm{~Hz}, \mathrm{H}-4$ and $\mathrm{H}-7)$, 
$8.13\left(\mathrm{~d}, 2 \mathrm{H}, J=8.55 \mathrm{~Hz}, \mathrm{H}-3\right.$ and H-8), $7.93\left(\mathrm{~d}, 4 \mathrm{H}, J=8.40 \mathrm{~Hz}, 2 \mathrm{H}-3^{\prime}\right.$ and $2 \mathrm{H}-5), 7.73(\mathrm{~s}, 2 \mathrm{H}, \mathrm{H}-5$ and $\mathrm{H}-6), 7.14(\mathrm{dd}, 4 \mathrm{H}, J=6.00$ and $1.50 \mathrm{~Hz}, 2 \mathrm{H}-3_{\text {pyr }}$ and $2 \mathrm{H}-5_{\text {pyr }}$ ), $3.67\left(\mathrm{t}, 4 \mathrm{H}, J=6.90 \mathrm{~Hz}, 2 \mathrm{NCH}_{2}\right), 2.73$ (t, $4 \mathrm{H}, J=6.90 \mathrm{~Hz}, 2 \mathrm{CH}_{2} \mathrm{Pyr}$ ), 2.08 (qt, $4 \mathrm{H}, J=6.90 \mathrm{~Hz}, 2 \mathrm{CH}_{2}$ ).

4.1.3 | General procedure for the synthesis of 2,9bis[4-(pyridinylalkylaminomethyl)phenyl]-1,10phenanthrolines $1 \mathbf{a}-\mathbf{i}$

To a solution of compounds $4 \mathrm{a}-\mathbf{i}(0.4 \mathrm{mmol})$ in methanol $(10 \mathrm{ml})$, sodium borohydride ( $2.4 \mathrm{mmol}, 6$ eq.) was added portion-wise at $0^{\circ} \mathrm{C}$. The reaction mixture was then stirred at room temperature for $2 \mathrm{~h}$. Then it was evaporated to dryness under reduced pressure. After cooling, the residue was triturated in water and extracted with dichloromethane $(40 \mathrm{ml})$. The organic layer was separated, dried over sodium sulfate and activated charcoal, and evaporated to dryness. The residue was then purified by column chromatography on silica gel using dichloromethane/methanol $(90: 10 \mathrm{v} / \mathrm{v})$ as an eluent to give the pure products $1 \mathbf{a}-\mathbf{i}$.

\section{2,9-Bis[4-(pyridin-2-ylmethylaminomethyl)phenyl]-1,10- \\ phenanthroline (1a)}

Pale-yellow crystals (yield, 90\%); m.p. $=69-71^{\circ} \mathrm{C} .{ }^{1} \mathrm{H} \mathrm{NMR}\left(\mathrm{CDCl}_{3}\right) \delta$ ppm: 8.60 (ddd, $2 \mathrm{H}, J=5.90,1.80$ and $0.90 \mathrm{~Hz}, 2 \mathrm{H}-6_{\text {pyr }}$ ), 8.45 (d, $4 \mathrm{H}$, $J=8.40 \mathrm{~Hz}, 2 \mathrm{H}-2^{\prime}$ and $2 \mathrm{H}-6$ ), 8.29 (d, 2H, $J=8.40 \mathrm{~Hz}, \mathrm{H}-4$ and $\mathrm{H}-7$ ), 8.14 (d, $2 \mathrm{H}, J=8.40 \mathrm{~Hz}, \mathrm{H}-3$ and $\mathrm{H}-8$ ), 7.77 (s, 2H, H-5 and $\mathrm{H}-6), 7.66$ (ddd, $2 \mathrm{H}$, $J=7.80,7.20$ and $\left.1.50 \mathrm{~Hz}, 2 \mathrm{H}-4_{\text {pyr }}\right), 7.60\left(\mathrm{~d}, 4 \mathrm{H}, J=8.40 \mathrm{~Hz}, 2 \mathrm{H}-3^{\prime}\right.$ and $2 \mathrm{H}-5$ ), 7.36 (ddd, $2 \mathrm{H}, J=7.20,0.90$ and $0.90 \mathrm{~Hz}, 2 \mathrm{H}-3_{\text {pyr }}$ ), 7.18 (ddd, $2 \mathrm{H}$, $J=7.80,5.90$ and $\left.0.90 \mathrm{~Hz}, 2 \mathrm{H}-5_{\text {pyr }}\right), 4.00$ (s, $\left.4 \mathrm{H}, 2 \mathrm{NCH}_{2}\right), 3.98$ (s, $4 \mathrm{H}$, $\left.2 \mathrm{NCH}_{2}\right) ;{ }^{13} \mathrm{C} \mathrm{NMR}\left(\mathrm{CDCl}_{3}\right) \delta$ ppm: 161.3 (C-2 $\left.{ }_{\text {pyr }}\right), 158.0$ (C-2), 150.7 (C$6_{\text {pyr }}$ ), 147.5 (C-1a and C-10a), 142.9 (C-1' and C-4), 139.6 (C-4a and C6a), 138.2 (C-4 and C-7), 137.9 (C-4 pyr), 130.1 (C-3' and C-5), 129.1 (C-2' and C-6), 127.3 (C-5 and C-6), 123.8 (C-3 pyr ), 123.4 (C-5 pyr), 121.2 (C-3 and $\mathrm{C}-8), 55.9\left(\mathrm{NCH}_{2}\right), 54.6\left(\mathrm{NCH}_{2}\right)$; matrix-assisted laser desorption/ ionization-time of flight (MALDI-TOF) $\mathrm{MS} \mathrm{m/z}[\mathrm{M}+\mathrm{H}]^{+}$calcd. for $\mathrm{C}_{38} \mathrm{H}_{33} \mathrm{~N}_{6}$ : 573.276, found: 573.276 .

\section{2,9-Bis[4-(pyridin-3-ylmethylaminomethyl)phenyl]-1,10-}

phenanthroline (1b)

Yellow oil (yield, 97\%). ${ }^{1} \mathrm{H} \mathrm{NMR}\left(\mathrm{CDCl}_{3}\right) \delta$ ppm: 8.60 (ddd, $2 \mathrm{H}, J=1.80$, 0.90 and $0.90 \mathrm{~Hz}, 2 \mathrm{H}-2_{\text {pyr }}$ ), 8.53 (dd, $2 \mathrm{H}, J=6.00$ and $1.50 \mathrm{~Hz}, 2 \mathrm{H}-6_{\text {pyr }}$ ), $8.46\left(\mathrm{~d}, 4 \mathrm{H}, J=8.40 \mathrm{~Hz}, 2 \mathrm{H}-2^{\prime}\right.$ and $\left.2 \mathrm{H}-6\right), 8.31(\mathrm{~d}, 2 \mathrm{H}, J=8.40 \mathrm{~Hz}, \mathrm{H}-4$ and $\mathrm{H}-7), 8.15(\mathrm{~d}, 2 \mathrm{H}, J=8.40 \mathrm{~Hz}, \mathrm{H}-3$ and $\mathrm{H}-8), 7.79$ (s, 2H, $\mathrm{H}-5$ and $\mathrm{H}-6$ ), 7.74 (ddd, $2 \mathrm{H}, J=7.80,1.80$ and $1.80 \mathrm{~Hz}, 2 \mathrm{H}-4_{\text {pyr }}$ ), 7.57 (d, $4 \mathrm{H}$, $J=8.40 \mathrm{~Hz}, 2 \mathrm{H}-3^{\prime}$ and $2 \mathrm{H}-5$ ), 7.29 (ddd, $2 \mathrm{H}, J=7.80,6.00$ and $0.90 \mathrm{~Hz}$, $2 \mathrm{H}-5_{\text {pyr }}$ ), 3.94 (s, $4 \mathrm{H}, 2 \mathrm{NCH}_{2}$ ), 3.87 (s, 4H, $2 \mathrm{NCH}_{2}$ ), 1.86 (bs, $2 \mathrm{H}, 2 \mathrm{NH}$ ); ${ }^{13} \mathrm{C} \mathrm{NMR}\left(\mathrm{CDCl}_{3}\right) \delta$ ppm: 157.9 (C-2), 151.2 (C-2 $\left.{ }_{\text {pyr }}\right), 149.9$ (C-6 $\left.6_{\text {pyr }}\right), 147.5$ (C-1a and C-10a), 142.7 (C-1' and C-4), 139.8 (C-3 ${ }_{\text {pyr }}$ ), 138.3 (C-4 and C7), 137.3 (C-4 pyr), 137.0 (C-4a and C-6a), 130.0 (C-3' and C-5), 129.2 (C2' and C-6), 127.4 (C-5 and C-6), 124.8 (C- $5_{\text {pyr }}$ ), 121.3 (C-3 and C-8), 54.3 $\left(\mathrm{NCH}_{2}\right), 51.7\left(\mathrm{NCH}_{2}\right)$; MALDI-TOF MS m/z $[\mathrm{M}+\mathrm{H}]^{+}$calcd. for $\mathrm{C}_{38} \mathrm{H}_{33} \mathrm{~N}_{6}$ : 573.276, found: 573.276 .
2,9-Bis[4-(pyridin-4-ylmethylaminomethyl)phenyl]-1,10-

phenanthroline (1c)

Yellow oil (yield, 83\%). ${ }^{1} \mathrm{H}$ NMR $\left(\mathrm{CDCl}_{3}\right) \delta$ ppm: 8.53 (dd, $4 \mathrm{H}, J=6.30$ and $1.80 \mathrm{~Hz}, 2 \mathrm{H}-2_{\mathrm{pyr}}$ and $\left.2 \mathrm{H}-6_{\mathrm{pyr}}\right), 8.42\left(\mathrm{~d}, 4 \mathrm{H}, J=8.40 \mathrm{~Hz}, 2 \mathrm{H}-2^{\prime}\right.$ and $2 \mathrm{H}-6), 8.25$ (d, $2 \mathrm{H}, J=8.55 \mathrm{~Hz}, \mathrm{H}-4$ and $\mathrm{H}-7), 8.09$ (d, $2 \mathrm{H}, J=8.55 \mathrm{~Hz}$, $\mathrm{H}-3$ and $\mathrm{H}-8$ ), 7.73 (s, $2 \mathrm{H}, \mathrm{H}-5$ and $\mathrm{H}-6), 7.52(\mathrm{~d}, 4 \mathrm{H}, J=8.40 \mathrm{~Hz}, 2 \mathrm{H}-$ $3^{\prime}$ and $2 \mathrm{H}-5$ ), $7.28\left(\mathrm{dd}, 4 \mathrm{H}, J=6.30\right.$ and $1.80 \mathrm{~Hz}, 2 \mathrm{H}-3_{\text {pyr }}$ and $2 \mathrm{H}$ $5_{\text {pyr }}$ ), 3.87 (s, $4 \mathrm{H}, 2 \mathrm{NCH}_{2}$ ), 3.80 (s, $4 \mathrm{H}, 2 \mathrm{NCH}_{2}$ ), 1.65 (bs, $2 \mathrm{H}, 2 \mathrm{NH}$ ); ${ }^{13} \mathrm{C} \mathrm{NMR}\left(\mathrm{CDCl}_{3}\right) \delta$ ppm: 157.8 (C-2), 151.1 (C-2 $2_{\text {pyr }}$ and $\left.\mathrm{C}-6_{\text {pyr }}\right)$, 150.8 (C-4 pyr), 147.4 (C-1a and C-10a), 142.6 (C-1' and C-4), 139.8 (C-4a and C-6a), 138.3 (C-4 and C-7), 130.0 (C-3' and C-5), 129.1 (C2' and C-6), 127.4 (C-5 and C-6), 124.4 (C-3 pyr $_{\text {and }}$ C- $5_{\text {pyr }}$ ), 121.2 (C3 and C-8), $54.2\left(\mathrm{NCH}_{2}\right), 53.0\left(\mathrm{NCH}_{2}\right)$; MALDI-TOF MS m/z [M+H] ${ }^{+}$ calcd. for $\mathrm{C}_{38} \mathrm{H}_{33} \mathrm{~N}_{6}$ : 573.276, found: 573.276.

\section{2,9-Bis[4-(pyridin-2-ylethylaminomethyl)phenyl]-1,10-}

phenanthroline (1d)

Pale-yellow oil (yield, 67\%). ${ }^{1} \mathrm{H}$ NMR $\left(\mathrm{CDCl}_{3}\right) \delta$ ppm: 8.55 (ddd, $2 \mathrm{H}$, $J=5.90,2.10$ and $\left.1.20 \mathrm{~Hz}, 2 \mathrm{H}-6_{\mathrm{pyr}}\right), 8.42\left(\mathrm{~d}, 4 \mathrm{H}, J=8.25 \mathrm{~Hz}, 2 \mathrm{H}-2^{\prime}\right.$ and $2 \mathrm{H}-6), 8.26(\mathrm{~d}, 2 \mathrm{H}, J=8.40 \mathrm{~Hz}, \mathrm{H}-4$ and $\mathrm{H}-7), 8.11(\mathrm{~d}, 2 \mathrm{H}$, $J=8.40 \mathrm{~Hz}, \mathrm{H}-3$ and $\mathrm{H}-8$ ), $7.74(\mathrm{~s}, 2 \mathrm{H}, \mathrm{H}-5$ and $\mathrm{H}-6$ ), 7.59 (ddd, $2 \mathrm{H}$, $J=7.80,7.20$ and $\left.2.10 \mathrm{~Hz}, 2 \mathrm{H}-4_{\mathrm{pyr}}\right), 7.53\left(\mathrm{~d}, 4 \mathrm{H}, J=8.25 \mathrm{~Hz}, 2 \mathrm{H}-3^{\prime}\right.$ and $2 \mathrm{H}-5$ ), 7.19 (ddd, $2 \mathrm{H}, J=7.20,1.20$ and $1.20 \mathrm{~Hz}, 2 \mathrm{H}-3_{\text {pyr }}$ ), 7.11 (ddd, $2 \mathrm{H}, J=7.80,5.90$ and $1.20 \mathrm{~Hz}, 2 \mathrm{H}-5_{\mathrm{pyr}}$ ), 3.96 (s, $4 \mathrm{H}, 2 \mathrm{NCH}_{2}$ ), $3.11\left(\mathrm{t}, 4 \mathrm{H}, J=6.70 \mathrm{~Hz}, 2 \mathrm{NCH}_{2}\right.$ ), 3.06 (t, $4 \mathrm{H}, J=6.70 \mathrm{~Hz}, 2 \mathrm{CH}_{2} \mathrm{Pyr}$ ), 1.94 (bs, $2 \mathrm{H}, 2 \mathrm{NH}) ;{ }^{13} \mathrm{C} \mathrm{NMR}\left(\mathrm{CDCl}_{3}\right) \delta$ ppm: 161.6 (C-2 $\left.{ }_{\text {pyr }}\right), 158.0$ (C2), 150.7 (C-6 pyr $_{\text {r }}$ ) 147.5 (C-1a and C-10a), 143.2 (C-1' and C-4), 139.5 (C-4a and C-6a), 138.2 (C-4 and C-7), 137.7 (C-4 pyr), 129.9 (C$3^{\prime}$ and C-5), 129.1 (C-2' and C-6), 127.3 (C-5 and C-6), 124.7 (C-3 pyr), 123.6 (C-5 $\left.5_{\text {pyr }}\right), 121.2$ (C-3 and C-8), $55.0\left(\mathrm{NCH}_{2}\right), 50.2\left(\mathrm{NCH}_{2}\right), 39.9$ $\left(\mathrm{CH}_{2} \text { Pyr); MALDI-TOF MS m/z [M+H] }\right]^{+}$calcd. for $\mathrm{C}_{40} \mathrm{H}_{37} \mathrm{~N}_{6}: 601.308$, found: 601.307

\section{2,9-Bis[4-(pyridin-3-ylethylaminomethyl)phenyl]-1,10-}

phenanthroline (1e)

Yellow oil (yield, 61\%). ${ }^{1} \mathrm{H}$ NMR $\left(\mathrm{CDCl}_{3}\right) \delta$ ppm: 8.48-8.38 (m, 8H, $2 \mathrm{H}-2_{\text {pyr }}, 2 \mathrm{H}-6_{\text {pyr }}, 2 \mathrm{H}-2^{\prime}$ and $2 \mathrm{H}-6$ ), 8.23 (d, $2 \mathrm{H}, J=8.40 \mathrm{~Hz}, \mathrm{H}-4$ and $\mathrm{H}-7$ ), 8.07 (d, $2 \mathrm{H}, \mathrm{J}=8.40 \mathrm{~Hz}, \mathrm{H}-3$ and $\mathrm{H}-8$ ), 7.69 (s, 2H, H-5 and $\mathrm{H}-6$ ), 7.52-7.43 (m, $6 \mathrm{H}, 2 \mathrm{H}-4_{\text {pyr }}, 2 \mathrm{H}-3^{\prime}$ and $2 \mathrm{H}-5$ ), 7.18 (ddd, $2 \mathrm{H}, J=7.80$, 6.00 and $\left.0.90 \mathrm{~Hz}, 2 \mathrm{H}-5_{\text {pyr }}\right), 3.87\left(\mathrm{~s}, 4 \mathrm{H}, 2 \mathrm{NCH}_{2}\right), 2.88$ (t, $4 \mathrm{H}$, $J=6.90 \mathrm{~Hz}, 2 \mathrm{NCH}_{2}$ ), $2.78\left(\mathrm{t}, 4 \mathrm{H}, J=6.90 \mathrm{~Hz}, 2 \mathrm{CH}_{2} \mathrm{Pyr}\right.$ ), 1.75 (bs, $2 \mathrm{H}$, $2 \mathrm{NH}) ;{ }^{13} \mathrm{C} \mathrm{NMR}\left(\mathrm{CDCl}_{3}\right) \delta$ ppm: 157.8 (C-2), 151.5 (C-2 $\left.{ }_{\text {pyr }}\right), 149.0$ (C$6_{\text {pyr }}$ ), 147.4 (C-1a and C-10a), 142.9 (C-1' and C-4), 139.7 (C-3 pyr), 138.3 (C-4 and C-7), 137.6 (C-4 pyr ), 136.9 (C-4a and C-6a), 129.9 (C$3^{\prime}$ and C-5), 129.1 (C-2' and C-6'), 127.4 (C-5 and C-6), 124.8 (C-5 pyr), $121.2(\mathrm{C}-3$ and $\mathrm{C}-8), 54.9\left(\mathrm{NCH}_{2}\right), 51.4\left(\mathrm{NCH}_{2}\right), 34.9\left(\mathrm{CH}_{2} \mathrm{Pyr}\right)$; MALDI-TOF MS m/z $[\mathrm{M}+\mathrm{H}]^{+}$calcd. for $\mathrm{C}_{40} \mathrm{H}_{37} \mathrm{~N}_{6}$ : 601.308, found: 601.308 .

\section{2,9-Bis[4-(pyridin-4-ylethylaminomethyl)phenyl]-1,10-}

phenanthroline (1f)

Yellow oil (yield, 97\%). ${ }^{1} \mathrm{H}$ NMR $\left(\mathrm{CDCl}_{3}\right) \delta$ ppm: 8.49 (dd, $4 \mathrm{H}, J=6.15$ and $1.65 \mathrm{~Hz}, 2 \mathrm{H}-2_{\text {pyr }}$ and $\left.2 \mathrm{H}-6_{\text {pyr }}\right), 8.41\left(\mathrm{~d}, 4 \mathrm{H}, J=8.10 \mathrm{~Hz}, 2 \mathrm{H}-2^{\prime}\right.$ and 
$2 \mathrm{H}-6$ ) , 8.25 (d, $2 \mathrm{H}, J=8.40 \mathrm{~Hz}, \mathrm{H}-4$ and $\mathrm{H}-7), 8.10(\mathrm{~d}, 2 \mathrm{H}, J=8.40 \mathrm{~Hz}$ $\mathrm{H}-3$ and $\mathrm{H}-8$ ), 7.73 (s, 2H, H-5 and $\mathrm{H}-6$ ), 7.48 (d, $4 \mathrm{H}, J=8.10 \mathrm{~Hz}, 2 \mathrm{H}-$ $3^{\prime}$ and $2 \mathrm{H}-5$ ), $7.12\left(\mathrm{dd}, 4 \mathrm{H}, J=6.15\right.$ and $1.65 \mathrm{~Hz}, 2 \mathrm{H}-3_{\mathrm{pyr}}$ and $2 \mathrm{H}$ 5 pyr), 3.89 (s, $4 \mathrm{H}, 2 \mathrm{NCH}_{2}$ ), $2.92\left(\mathrm{t}, 4 \mathrm{H}, J=6.60 \mathrm{~Hz}, 2 \mathrm{NCH}_{2}\right.$ ), 2.81 (t, $\left.4 \mathrm{H}, J=6.60 \mathrm{~Hz}, 2 \mathrm{CH}_{2} \mathrm{Pyr}\right), 1.91$ (bs, $\left.2 \mathrm{H}, 2 \mathrm{NH}\right) ;{ }^{13} \mathrm{C} \mathrm{NMR}\left(\mathrm{CDCl}_{3}\right) \delta$ ppm: 157.9 (C-2), 151.2 (C-2 $2_{\text {pyr }}$ and C-6 ${ }_{\text {pyr }}$ ), 150.5 (C-4 $4_{\text {pyr }}$ ), 147.4 (C1a and C-10a), 142.8 (C-1' and C-4), 139.7 (C-4a and C-6a), 138.3 (C4 and C-7), 129.9 (C-3' and C-5'), 129.1 (C-2' and C-6), 127.3 (C-5 and C-6), 125.6 (C-3 pyr $_{\text {and }} \mathrm{C}-5_{\text {pyr }}$ ), 121.2 (C-3 and C-8), $54.9\left(\mathrm{NCH}_{2}\right)$, $50.6\left(\mathrm{NCH}_{2}\right), 37.2\left(\mathrm{CH}_{2}\right.$ Pyr $)$; MALDI-TOF MS m/z [M+H] ${ }^{+}$calcd. for $\mathrm{C}_{40} \mathrm{H}_{37} \mathrm{~N}_{6}: 601.308$, found: 601.308.

\section{2,9-Bis[4-(pyridin-2-ylpropylaminomethyl)phenyl]-1,10-}

phenanthroline (1g)

Yellow oil (yield, 97\%). ${ }^{1} \mathrm{H}$ NMR $\left(\mathrm{CDCl}_{3}\right) \delta$ ppm: 8.48 (ddd, $2 \mathrm{H}$, $J=6.00,1.80$ and $\left.0.90 \mathrm{~Hz}, 2 \mathrm{H}-6_{\text {pyr }}\right), 8.39\left(\mathrm{~d}, 4 \mathrm{H}, J=8.40 \mathrm{~Hz}, 2 \mathrm{H}-2^{\prime}\right.$ and $2 \mathrm{H}-6$ ), 8.19 (d, $2 \mathrm{H}, J=8.70 \mathrm{~Hz}, \mathrm{H}-4$ and $\mathrm{H}-7$ ), 8.05 (d, $2 \mathrm{H}$, $J=8.70 \mathrm{~Hz}, \mathrm{H}-3$ and $\mathrm{H}-8$ ), 7.66 (s, $2 \mathrm{H}, \mathrm{H}-5$ and $\mathrm{H}-6$ ), 7.53 (ddd, $2 \mathrm{H}$, $J=7.80,7.20$ and $\left.1.80 \mathrm{~Hz}, 2 \mathrm{H}-4_{\text {pyr }}\right), 7.50\left(\mathrm{~d}, 4 \mathrm{H}, J=8.40 \mathrm{~Hz}, 2 \mathrm{H}-3^{\prime}\right.$ and $2 \mathrm{H}-5$ ), 7.09 (ddd, $2 \mathrm{H}, J=7.20,0.90$ and $0.90 \mathrm{~Hz}, 2 \mathrm{H}-3_{\text {pyr }}$ ), 7.03 (ddd, $2 \mathrm{H}, J=7.80,6.00$ and $0.90 \mathrm{~Hz}, 2 \mathrm{H}-5_{\text {pyr }}$ ), $3.86\left(\mathrm{~s}, 4 \mathrm{H}, 2 \mathrm{NCH}_{2}\right.$ ), $2.84\left(\mathrm{t}, 4 \mathrm{H}, J=7.20 \mathrm{~Hz}, 2 \mathrm{NCH}_{2}\right.$ ), 2.71 (t, $4 \mathrm{H}, J=7.20 \mathrm{~Hz}, 2 \mathrm{CH}_{2} \mathrm{Pyr}$ ), 2.07 (bs, $2 \mathrm{H}, 2 \mathrm{NH}$ ), 1.96 (qt, $4 \mathrm{H}, J=7.20 \mathrm{~Hz}, 2 \mathrm{CH}_{2}$ ); ${ }^{13} \mathrm{C} \mathrm{NMR}$ $\left(\mathrm{CDCl}_{3}\right) \delta$ ppm: 163.2 (C-2 pyr $), 157.9$ (C-2), 150.5 (C-6 $\left.6_{\text {pyr }}\right), 147.4$ (C1a and C-10a), 143.2 (C-1' and C-4), 139.5 (C-4a and C-6a), 138.2 (C4 and C-7), 137.7 (C-4 pyr), 129.9 (C-3' and C-5), 129.0 (C-2' and C-6), 127.3 (C-5 and C-6), 124.2 (C-3 pyr ), 122.4 (C-5 pyr ), 121.2 (C-3 and C8), $55.0\left(\mathrm{NCH}_{2}\right), 50.1\left(\mathrm{NCH}_{2}\right), 37.4\left(\mathrm{CH}_{2} \mathrm{Pyr}\right), 31.4\left(\mathrm{CH}_{2}\right)$; MALDI-TOF MS m/z $[\mathrm{M}+\mathrm{H}]^{+}$calcd. for $\mathrm{C}_{42} \mathrm{H}_{41} \mathrm{~N}_{6}$ : 629.339, found: 629.506 .

\section{2,9-Bis[4-(pyridin-3-ylpropylaminomethyl)phenyl]-1,10-}

phenanthroline (1h)

Yellow oil (yield, 86\%). ${ }^{1} \mathrm{H}$ NMR $\left(\mathrm{CDCl}_{3}\right) \delta \mathrm{ppm}$ : 8.46 (ddd, $2 \mathrm{H}$, $J=1.80,0.90$ and $\left.0.90 \mathrm{~Hz}, 2 \mathrm{H}-2_{\text {pyr }}\right), 8.44-8.40\left(\mathrm{~m}, 6 \mathrm{H}, 2 \mathrm{H}-6_{\mathrm{pyr}}, 2 \mathrm{H}\right.$ $2^{\prime}$ and $2 \mathrm{H}-6$ ), 8.26 (d, $2 \mathrm{H}, J=8.40 \mathrm{~Hz}, \mathrm{H}-4$ and $\mathrm{H}-7$ ), 8.11 (d, $2 \mathrm{H}$, $J=8.40 \mathrm{~Hz}, \mathrm{H}-3$ and $\mathrm{H}-8$ ), $7.74(\mathrm{~s}, 2 \mathrm{H}, \mathrm{H}-5$ and $\mathrm{H}-6), 7.52(\mathrm{~d}, 4 \mathrm{H}$, $J=8.40 \mathrm{~Hz}, 2 \mathrm{H}-3^{\prime}$ and $2 \mathrm{H}-5$ ), 7.47 (ddd, $2 \mathrm{H}, J=7.80,1.80$ and $1.80 \mathrm{~Hz}, 2 \mathrm{H}-4_{\text {pyr }}$ ), 7.18 (ddd, $2 \mathrm{H}, J=7.80,5.70$ and $0.90 \mathrm{~Hz}, 2 \mathrm{H}$ 5 pyr), $3.88\left(\mathrm{~s}, 4 \mathrm{H}, 2 \mathrm{NCH}_{2}\right), 2.70\left(\mathrm{t}, 4 \mathrm{H}, J=7.05 \mathrm{~Hz}, 2 \mathrm{NCH}_{2}\right), 2.68$ (t, $4 \mathrm{H}, J=7.05 \mathrm{~Hz}, 2 \mathrm{CH}_{2} \mathrm{Pyr}$ ), 1.91 (bs, $2 \mathrm{H}, 2 \mathrm{NH}$ ), 1.85 (qt, $4 \mathrm{H}$, $\left.J=7.05 \mathrm{~Hz}, 2 \mathrm{CH}_{2}\right) ;{ }^{13} \mathrm{C} \mathrm{NMR}\left(\mathrm{CDCl}_{3}\right) \delta$ ppm: $157.8(\mathrm{C}-2), 151.2(\mathrm{C}$ $2_{\text {pyr }}$ ), 148.6 (C-6 pyr ), 147.4 (C-1a and C-10a), 143.1 (C-1' and C-4'), 139.5 (C-3 pyr), 138.7 (C-4a and C-6a), 138.2 (C-4 and C-7), 137.1 (C-4 pyr), 129.9 (C-3' and C-5'), 129.1 (C-2' and C-6'), 127.2 (C-5 and C-6), 124.6 (C-5 pyr), 121.1 (C-3 and C-8), $55.0\left(\mathrm{NCH}_{2}\right), 49.8\left(\mathrm{NCH}_{2}\right)$, $32.7\left(\mathrm{CH}_{2}\right.$ Pyr), $32.0\left(\mathrm{CH}_{2}\right)$; MALDI-TOF MS m/z [M+H] ${ }^{+}$calcd. for $\mathrm{C}_{42} \mathrm{H}_{41} \mathrm{~N}_{6}$ : 629.339, found: 629.423 .

\section{2,9-Bis[4-(pyridin-4-ylpropylaminomethyl)phenyl]-1,10-} phenanthroline (1i)

Pale-yellow oil (yield, 98\%). ${ }^{1} \mathrm{H}$ NMR $\left(\mathrm{CDCl}_{3}\right) \delta$ ppm: 8.47 (dd, $4 \mathrm{H}$, $J=6.10$ and $1.50 \mathrm{~Hz}, 2 \mathrm{H}-2_{\mathrm{pyr}}$ and $\left.2 \mathrm{H}-6_{\mathrm{pyr}}\right), 8.42(\mathrm{~d}, 4 \mathrm{H}, J=8.40 \mathrm{~Hz}$, $2 \mathrm{H}-2^{\prime}$ and $2 \mathrm{H}-6$ '), 8.27 (d, $2 \mathrm{H}, J=8.40 \mathrm{~Hz}, \mathrm{H}-4$ and $\mathrm{H}-7$ ), 8.11 (d,
$2 \mathrm{H}, J=8.40 \mathrm{~Hz}, \mathrm{H}-3$ and $\mathrm{H}-8$ ), 7.73 (s, 2H, H-5 and $\mathrm{H}-6$ ), 7.51 (d, $4 \mathrm{H}, J=8.40 \mathrm{~Hz}, 2 \mathrm{H}-3^{\prime}$ and $2 \mathrm{H}-5$ ), 7.09 (dd, $4 \mathrm{H}, J=6.10$ and $1.50 \mathrm{~Hz}, 2 \mathrm{H}-3_{\text {pyr }}$ and $\left.2 \mathrm{H}-5_{\text {pyr }}\right), 3.87$ (s, $4 \mathrm{H}, 2 \mathrm{NCH}_{2}$ ), 2.67 (t, $4 \mathrm{H}$, $J=7.10 \mathrm{~Hz}, 2 \mathrm{NCH}_{2}$ ), 2.65 (t, $4 \mathrm{H}, J=7.10 \mathrm{~Hz}, 2 \mathrm{CH}_{2} \mathrm{Pyr}$ ), 1.83 (qt, $\left.4 \mathrm{H}, J=7.10 \mathrm{~Hz}, 2 \mathrm{CH}_{2}\right), 1.65$ (bs, $\left.2 \mathrm{H}, 2 \mathrm{NH}\right) ;{ }^{13} \mathrm{C} \mathrm{NMR}\left(\mathrm{CDCl}_{3}\right) \delta$ ppm: 157.9 (C-2), 152.3 (C-4 pyr $), 151.1$ (C-2 $2_{\text {pyr }}$ and C-6 $6_{\text {pyr }}$ ), 147.4 (C-1a and C-10a), 143.2 (C-1' and C-4'), 139.6 (C-4a and C-6a), 138.3 (C-4 and C-7), 129.9 (C-3' and C-5'), 129.1 (C-2' and C-6'), 127.3 (C-5 and C-6), 125.3 (C-3 $3_{\text {pyr }}$ and C-5 pyr), 121.2 (C-3 and C-8), $55.1\left(\mathrm{NCH}_{2}\right), 49.9\left(\mathrm{NCH}_{2}\right), 34.3\left(\mathrm{CH}_{2} \mathrm{Pyr}\right), 32.0\left(\mathrm{CH}_{2}\right)$; MALDI-TOF MS m/z [M+H] $]^{+}$calcd. for $\mathrm{C}_{42} \mathrm{H}_{41} \mathrm{~N}_{6}$ : 629.339, found: 629.339.

\section{2 | Biological evaluation}

\subsection{1 | Cell cultures and reagents}

KU812, K562, and MV4-11 cell lines were obtained from the Deutshe Sammlung von Mikroorganismens und Zellkulturen (DSMZ). HL60, U937, HS-27, and HuT78 cell lines were obtained from the American Type Culture Collection (ATCC).

BM-mesenchymal stem cells (MSCs) from brain dead donors were isolated and cultured, as described. Informed consent was obtained before BM samples were taken. MSCs were cultured in aMEM with $2 \mathrm{mM}$ glutamine, $100 \mathrm{U} / \mathrm{ml}$ penicillin, $100 \mu \mathrm{g} / \mathrm{ml}$ streptomycin, $0.005 \%$ fibroblast growth factor 2 (Gibco-Thermo Fisher Scientific), and $10 \%$ fetal bovine serum (Gibco-Thermo Fisher Scientific), at $37^{\circ} \mathrm{C}, 5 \% \mathrm{CO}_{2}$.

\subsection{2 | Cell proliferation assays}

Cell viability and proliferation were studied using either MTS (3-(4,5dimethylthiazol-2-yl)-5-(3-carboxymethoxyphenyl)-2-(4-sulfophenyl)-2 $\mathrm{H}$ tetrazolium) or MTT (3-(4,5-dimethylthiazol-2-yl)-2,5-diphenyltetrazolium bromide) cell proliferation assays.

The MTS cell proliferation assay (Promega) is a colorimetric assay system that measures the reduction of a tetrazolium component (MTS) into formazan produced by the mitochondria of viable cells. Cells were washed twice in phosphate-buffered saline (PBS) and plated in quadruplicate into microtiter plate wells in $100 \mu \mathrm{l}$ ( $10^{4}$ leukemic cells) of culture media with or without our various compounds at increasing concentrations ( 0 , $1,5,10,20$, and $50 \mu \mathrm{M}$ ) for 1,2 , and 3 days. After $3 \mathrm{~h}$ of incubation at $37^{\circ} \mathrm{C}$ with $20 \mu \mathrm{l} \mathrm{MTS} /$ well, the plates were read by using an ELISA microplate reader (iMark; Bio-Rad) at $490 \mathrm{~nm}$ wavelength. The amount of color produced was directly proportional to the number of viable cells. The results are expressed as the concentrations inhibiting cell growth by $50 \%$ after a 3 -day incubation period. The $50 \%$ inhibitory concentrations $\left(I_{50}\right)$ were determined by linear regression analysis, expressed in $\mu \mathrm{M} \pm S D$ (Microsoft Excel). 
For MTT cell proliferation assay, briefly, $0.2 \times 10^{5}$ leukemic cells were incubated in $100 \mu \mathrm{l}$ of RPMI red phenol-free medium (Thermo Fisher Scientific) in 96-well plates. In initial screening assays, cells were incubated with $10 \mu \mathrm{M}$ of each compound for 24,48 , and $72 \mathrm{~h}$. To determine the concentration effect of the molecules, cells were treated with concentrations ranging from $100 \mathrm{nM}$ to $100 \mu \mathrm{M}$ for $48 \mathrm{~h}$. Then, $0.1 \times 10^{5} \mathrm{HS} 27 \mathrm{a}$ cells and $0.035 \times 10^{5} \mathrm{MSC}$ were incubated in $100 \mu \mathrm{l}$ of RPMI red phenol-free medium in 96-well plates for $48 \mathrm{~h}$ and then treated with concentrations ranging from $100 \mathrm{nM}$ to $100 \mu \mathrm{M}$ for $48 \mathrm{~h}$.

Cells were incubated with $10 \mu$ l of MTT working solution ( $5 \mathrm{~g} / \mathrm{l}$ of methylthiazolyldiphenyl-tetrazolium bromide from Sigma-Aldrich) for $4 \mathrm{~h}$. Cells were then lysed overnight at $37^{\circ} \mathrm{C}$ with $100 \mu \mathrm{l}$ of $10 \%$ sodium dodecyl sulfate and $0.003 \% \mathrm{HCl}$. Optical density at $570 \mathrm{~nm}$ was measured using a spectrophotometer CLARIOstar ${ }^{\circledR}$ (BMG Labtech).

\subsection{3 | FRET melting experiments}

FRET melting experiments were run on a Stratagene Mx3005P real-time PCR equipment in 96-well plates on the DNA sequences reported in Table 1. Experiments were performed in $10 \mathrm{mM}$ lithium cacodylate buffer $(\mathrm{pH} \mathrm{7.2)}$ and either $10 \mathrm{mM} \mathrm{KCl}$ and $90 \mathrm{mM} \mathrm{LiCl}$ (FK-RAST, FBcl-2T, F21T, and FdxT) or $1 \mathrm{mM} \mathrm{KCl}$ and $99 \mathrm{mM} \mathrm{LiCl}$ (FC-MYCT) concentrations, depending on the $T_{\mathrm{m}}$ of the G4s alone (Table 5). The DNA concentration was $0.2 \mu \mathrm{M}$. The stabilization $\left(\Delta T_{\mathrm{m}}\right)$ induced by compounds was calculated as the difference between the mid-transition temperature of the nucleic acid alone and measured with the relevant ligand concentration, $2 \mu \mathrm{M}$. Data are presented as an average of three independent measurements, each conducted in duplicate conditions $\left(\lambda_{\mathrm{exc}}=492 \mathrm{~nm}, \lambda_{\mathrm{em}}=516 \mathrm{~nm}, T\right.$ interval $=25-95^{\circ} \mathrm{C}$, ramp: $25^{\circ} \mathrm{C}$ for $5 \mathrm{~min}$, then $1^{\circ} \mathrm{C} / \mathrm{min}$, measurements every $1^{\circ} \mathrm{C}$, $\times 8$ magnification of the fluorescence signal).

\subsection{4 | Telomerase assays}

Telomerase activity was assessed in two leukemic cell lines, MV4-11 and HuT78. The TRAP assay (TRAPeze Telomerase Detection Kit; S7700; Millipore) was performed according to manufacturer's instructions, with some modifications. Briefly, $10^{6}$ cells were resuspended in CHAPS lysis buffer and proteins were extracted. Protein extracts were used to extend a synthetic telomeric DNA by PCR amplification $\left(1 \mathrm{cycle}\right.$ of $30^{\circ} \mathrm{C}$ for $30 \mathrm{~min}$, telomere template extension with hotstart DNA polymerase activation, followed by a telomeric PCR amplification: $95^{\circ} \mathrm{C}$ for $3 \mathrm{~min}, 2 \mathrm{cycles}$ of $95^{\circ} \mathrm{C}$ for $20 \mathrm{~s}$, and $49^{\circ} \mathrm{C}$ for $20 \mathrm{~s}$, and then 30 cycles of $95^{\circ} \mathrm{C}$ for $20 \mathrm{~s}$ and $60^{\circ} \mathrm{C}$ for $20 \mathrm{~s}$ with signal acquisition) in a Stratagene Mx3005P system (Agilent Technologies) using specific telomeric PCR quantitative primers. ${ }^{[35]}$ Each sample was measured in triplicate with a control DNA.

\section{3 | Mass spectrometry}

The affinity and stoichiometry of binding to G4-forming oligonucleotide were determined by electrospray mass spectrometry in a negative ion mode on a Thermo Orbitrap Exactive mass spectrometer calibrated daily, and operated in negative mode, on a $350-2800 \mathrm{~m} / \mathrm{z}$ scan range, using the 50,000 resolution setting, with the following tuning parameters: spray voltage: $3.1 \mathrm{kV}$, capillary temperature: $265^{\circ} \mathrm{C}$, sheath gas: 50 , aux gas: 0 , heater temperature: $35^{\circ} \mathrm{C}$, tube lens voltage: $-185 \mathrm{~V}$, capillary voltage: $-50 \mathrm{~V}$, skimmer voltage: $-25 \mathrm{~V}$. The syringe injection flow rate was $5 \mu \mathrm{l} /$ $\min$. These parameters ensured a good signal intensity without disruption of the noncovalent complexes. Oligonucleotides were purchased lyophilized and RP-cartridge purified from Eurogentec, TMAA (1 M) was purchased from Santa Cruz Biotechnology and potassium chloride $(\mathrm{KCl}$ >99.99\%) from Sigma-Aldrich. The injected solutions were prepared by diluting the proper volume of the oligonucleotide stock solutions to reach $10 \mu \mathrm{M}$ of DNA and $20 \mu \mathrm{M}$ of ligand, in $100 \mathrm{mM}$ TMAA and $1 \mathrm{mM} \mathrm{KCl}$. The solutions were incubated for $16 \mathrm{~h}$ at $4^{\circ} \mathrm{C}$ before analysis.

The abundance of each species, $M_{i} L_{j}$, where $M$ is a monomer oligonucleotide and $L$ is a ligand, was determined from their peak area intensities, $I_{\text {MiLj }}$, from the $4^{-}$and $5^{-}$charge states:

$$
A_{M_{i} L_{j}}=\frac{I_{M_{i} L_{j}}}{\sum_{i=1, j=0}^{n, m}\left(i \times I_{M_{i} L_{j}}\right)} .
$$

The molar concentrations were then calculated knowing the total amount of oligonucleotide $[\mathrm{M}]_{0}$ :

$$
\left[M_{i} L_{j}\right]=A_{M_{i} L_{j}} \times[M]_{0}=\frac{I_{M_{i} L_{j}} \times[M]_{0}}{\sum_{i=1, j=0}^{n, m}\left(i \times I_{M_{i} L_{j}}\right)} .
$$

The binding affinities for 1:1 and 2:1 L:M complex formation were determined from their dissociation constants:

$$
\begin{gathered}
M+L \rightleftarrows M L ; K_{d 1}=\frac{[L]_{\text {free }} \times[M]_{\text {free }}}{[M L]}, \\
M L+L \rightleftarrows M L_{2} ; K_{d 2}=\frac{[L]_{\text {free }} \times[M L]}{\left[M L_{2}\right]} .
\end{gathered}
$$

where the amount of free ligand is calculated from its total concentration $[L]_{0}$ :

$$
[L]_{\text {free }}=\left[L_{0}\right]-\sum_{i=1, j=1}^{n, m}\left(j \times\left[M_{i} L_{j}\right]\right) .
$$

The affinities were reported as $p K_{d}=-\log \left(K_{d}\right)$.

\subsection{Circular dichroism (CD)}

CD experiments were performed with a JASCO J-1500 spectropolarimeter using quartz cells of $2 \mathrm{~mm}$ path length. The scans were recorded at $22^{\circ} \mathrm{C}$, from 220 to $350 \mathrm{~nm}$ with the following parameters: $1.0 \mathrm{~nm}$ data pitch, $2 \mathrm{~nm}$ bandwidth, $0.5 \mathrm{~s}$ response, $50 \mathrm{~nm} / \mathrm{min}$ scanning 
Archiv der Pharmazie

speed; they are the result of three accumulations. Solutions were prepared as described in Section 4.3. The CD data were blank-subtracted and then normalized to molar dichroic absorption $\left(\Delta \varepsilon\right.$, in $\left.\mathrm{cm}^{-1} \cdot \mathrm{M}^{-1}\right)$ using the equation below, where $\theta$ is the ellipticity in millidegrees, $C$ is the oligonucleotide concentration in $\mathrm{mol} / \mathrm{l}$, and $I$ is the path length in centimeters:

$$
\Delta \varepsilon=\frac{\theta}{32,980 \times C \times 1}
$$

\section{ACKNOWLEDGMENTS}

This study was supported by a grant from Ligue Contre le Cancer (Comité Aquitaine-Charentes \& Aquitaine-Dordogne, Bordeaux, France). The authors thank the IECB platform.

\section{CONFLICTS OF INTERESTS}

The authors declare that there are no conflicts of interests.

\section{ORCID}

Jean Guillon (D) https://orcid.org/0000-0001-8577-3894

\section{REFERENCES}

[1] S. Fernandez, V. Desplat, A. Villacreces, A. V. Guitart, N. Milpied, A. Pigneux, I. Vigon, J.-M. Pasquet, P.-Y. Dumas, Int. J. Mol. Sci. 2019, 20, E3429.

[2] T. Hao, M. Li-Talley, A. Buck, W. Chen, Sci. Rep. 2019, 9, 12070.

[3] K. H. Metzeler, T. Herold, M. Rothenberg-Thurley, S. Amler, M. C. Sauerland, D. Görlich, S. Schneider, N. P. Konstandin, A. Dufour, K. Bräundl, B. Ksienzyk, E. Zellmeier, L. Hartmann, P. A. Greif, M. Fiegl, M. Subklewe, S. K. Bohlander, U. Krug, A. Faldum, W. E. Berdel, B. Wörmann, T. Büchner, W. Hiddemann, J. Braess, K. Spiekermann, Blood 2016, 128, 686.

[4] D. Gomez, T. Wenner, B. Brassart, C. Douarre, M. F. O'Donohue, V. El Khoury, K. Shin-Ya, H. Morjani, C. Trentesaux, J.-F. Riou, J. Biol. Chem. 2006, 281, 38721.

[5] M. Ivancich, Z. Schrank, L. Wojdyla, B. Leviskas, A. Kuckovic, A. Sanjali, N. Puri, Antioxidants 2017, 6, E15.

[6] D. L. Mengual Gomez, R. G. Armando, C. S. Cerrudo, P. D. Ghiringhelli, D. E. Gomez, Curr. Med. Chem. 2016, 16, 2432.

[7] N. Lipinska, A. Romaniuk, A. Paszel-Jaworska, E. Toton, P. Kopczynski, B. Rubis, Cell. Mol. Life Sci. 2017, 74, 4121.

[8] S. G. Zidanloo, A. H. Colagar, H. Ayatollahi, Z. Bagheryan, J. Biosci. 2019, 44, 12

[9] S. Asamitsu, S. Obata, Z. Yu, T. Bando, H. Sugiyama, Molecules 2019 24, 429.

[10] Z.-Y. Sun, X.-N. Wang, S.-Q. Cheng, X.-X. Su, T.-M. Ou, Molecules 2019, 24, 396

[11] T. Che, Y.-Q. Wang, Z. L. Huang, J.-H. Tan, Z.-S. Huang, S. B. Chen, Molecules 2018, 23, 493.

[12] A. R. Duarte, E. Cadoni, A. S. Ressurreição, R. Moreira, A. Paulo, ChemMedChem 2018, 13, 869.

[13] N. S. Ilyinsky, A. M. Varizhuk, A. D. Beniaminov, M. A. Puzanov, A. K. Shchyolkina, D. N. Kaluzhny, Mol. Biol. 2014, 48, 778.

[14] J. N. Liu, J. F. Guo, J. M. Zhou, G. K. Feng, Z. S. Huang, L. Q. Gu, Y. X. Zeng, X. F. Zhu, Leukemia 2007, 21, 1300

[15] H. Zhang, A. Local, K. Benbatoul, P. Folger, S. Sheng, L. Esquivies, J. Lightfoot, A. Vellanki, W. G. Rice, Blood 2016, 128, 1716.
[16] A. Local, H. Zhang, K. D. Benbatoul, P. Folger, X. Sheng, C.-Y. Tsai, S. B. Howell, W. G. Rice, Mol. Cancer Ther. 2018, 17, 1177.

[17] A. Cercek, J. Wheler, P. E. Murray, S. Zhou, L. Saltz, Invest. New Drugs 2015, 33, 1086.

[18] V. Desplat, M. Vincenzi, R. Lucas, S. Moreau, S. Savrimoutou, N. Pinaud, J. Lesbordes, E. Peyrilles, M. Marchivie, S. Routier, P. Sonnet, F. Rossi, L. Ronga, J. Guillon, Eur. J. Med. Chem. 2016, 113, 214.

[19] V. Desplat, M. Vincenzi, R. Lucas, S. Moreau, S. Savrimoutou, S. Rubio, N. Pinaud, D. Bigat, E. Enriquez, M. Marchivie, S. Routier, P. Sonnet, F. Rossi, L. Ronga, J. Guillon, ChemMedChem 2017, 12, 940.

[20] J. Guillon, M. Vincenzi, N. Pinaud, L. Ronga, F. Rossi, S. Savrimoutou, S. Moreau, V. Desplat, M. Marchivie, Struct. Chem. Crystallogr. Commun. 2016, 2, 1.

[21] J. Guillon, S. Savrimoutou, S. Rubio, V. Desplat, Molbank 2018 2018, M1023. https://doi.org/10.3390/M1023

[22] R. N. Das, E. Chevret, V. Desplat, S. Rubio, J.-L. Mergny, J. Guillon, Molecules 2018, 23, 81.

[23] J. Guillon, S. Savrimoutou, S. Rubio, S. Moreau, N. Pinaud, M. Marchivie, V. Desplat, Molbank 2020, 2020, M1113. https://doi. org/10.3390/M1113

[24] N. M. Gueddouda, M. R. Hurtado, S. Moreau, L. Ronga, R. N. Das, S. Savrimoutou, S. Rubio, A. Marchand, O. Mendoza, M. Marchivie, L. Elmi, A. Chansavang, V. Desplat, V. Gabelica, A. Bourdoncle, J.-L. Mergny, J. Guillon, ChemMedChem 2017, 12, 146.

[25] J. Guillon, A. Cohen, R. Nath Das, C. Boudot, N. Meriem Gueddouda, S. Moreau, L. Ronga, S. Savrimoutou, L. Basmaciyan, C. Tisnerat, S. Mestanier, S. Rubio, S. Amaziane, A. Dassonville-Klimpt, N. Azas, B. Courtioux, J.-L. Mergny, C. Mullié, P. Sonnet, Chem. Biol. Drug Des. 2018, 91, 974.

[26] A. De Cian, E. Delemos, J.-L. Mergny, M.-P. Teulade-Fichou, D. Monchaud, J. Am. Chem. Soc. 2007, 129, 1856.

[27] A. Marchand, V. Gabelica, J. Am. Soc. Mass Spectrom. 2014, 25, 1146.

[28] J. Dai, D. Chen, R. Jones, L. H. Hurley, D. Yang, Nucleic Acids Res. 2006, 34, 5133.

[29] K. N. Luu, A. T. Phan, V. Kuryavyi, L. Lacroix, Patel D. J., J. Am. Chem. Soc. 2006, 128, 9963.

[30] A. Ambrus, D. Chen, J. Dai, R. A. Jones, D. Yang, Biochemistry 2005 , 44, 2048.

[31] A. Ghosh, E. Largy, V. Gabelica, Nucleic Acids Res. 2021, 49, 2333.

[32] A. De Rache, J.-L. Mergny, Biochimie 2015, 115, 194.

[33] W. J. Chung, B. Heddi, F. Hamon, M.-P. Teulade-Fichou, A. Tuân Phan, Angew. Chem. Int. Ed. 2014, 53, 999.

[34] A. Perez, I. Marchan, D. Svozil, J. Sponer, T. E. Cheatham, C. A. Laughton, M. Orozco, Biophys. J. 2007, 92, 3817.

[35] R. M. Cawthon, Nucleic Acids Res. 2009, 37, e21. https://doi.org/10. 1093/nar/gkn1027

\section{SUPPORTING INFORMATION}

Additional Supporting Information may be found online in the supporting information tab for this article.

How to cite this article: J. Guillon, C. Denevault-Sabourin,

E. Chevret, M. Brachet-Botineau, V. Milano, A. Guédin-

Beaurepaire, S. Moreau, L. Ronga, S. Savrimoutou, S. Rubio,

J. Ferrer, J. Lamarche, J. Mergny, M. Viaud-Massuard,

M. Ranz, E. Largy, V. Gabelica, F. Rosu, F. Gouilleux,

V. Desplat, Arch. Pharm. 2021, 354, e2000450.

https://doi.org/10.1002/ardp.202000450 